\title{
A review of rare and less well known extant marine organic- walled dinoflagellate cyst taxa of the orders Gonyaulacales and Suessiales from the Northern Hemisphere
}

Limoges Audrey ${ }^{1,{ }^{*}}$, Van Nieuwenhove Nicolas ${ }^{1}$, Head Martin J. ${ }^{2}$, Mertens Kenneth ${ }^{3}$, Pospelova Vera ${ }^{4}$, Rochon André ${ }^{5}$

${ }^{1}$ Department of Earth Sciences, University of New Brunswick, 2 Bailey Drive, Fredericton, NB E3B 5A3, Canada

2 Department of Earth Sciences, Brock University, 1812 Sir Isaac Brock Way, St. Catharines, ON L2S

3A1, Canada

${ }^{3}$ LER BO, Station de Biologie Marine, Ifremer, Place de la Croix, BP40537, F-29185 Concarneau

CEDEX, France

${ }^{4}$ School of Earth and Ocean Sciences, University of Victoria, Bob Wright Centre A405, PO Box 1700,

STN CSC, Victoria, BC, Canada

${ }^{5}$ Institut des sciences de la mer de Rimouski, Université du Québec à Rimouski, 310 allée des

Ursulines, Rimouski, QC G5L 3A1, Canada

Corresponding author : Audrey Limoges, email address : alimoges@unb.ca

\begin{abstract}
:
Dinoflagellate resting cysts with rare exception produce the only discrete link between the biology of extant dinoflagellate species and their fossil record. The geological preservability of such cysts allows them to be used for quantitative paleoecological reconstructions, especially in the Quaternary, and for biostratigraphy and the calibration of molecular clocks with the geological record. This contribution reviews and updates the taxonomy of 27 uncommon dinoflagellate cyst species and morphotypes belonging to the orders Gonyaulacales and Suessiales with occurrences in upper Quaternary marine sediments of the Northern Hemisphere. Comparative descriptions and illustrations are provided along with the biological affinity of each taxon where known and lowest stratigraphic occurrence.
\end{abstract}

\section{Highlights}

- 25 rare or endemic extant dinoflagellate cyst species and two morphotypes are briefly described and illustrated. 23 belong to the Gonyaulacales and 4 to the Suessiales. Their stratigraphic ranges are provided.

Keywords : Dinoflagellate cysts, Gonyaulacales, Suessiales, Marine sediment, Quaternary 


\section{Introduction}

Organic-walled dinoflagellate cysts are a common component of the marine sedimentary fraction in both coastal and oceanic settings and represent a specific stage (presumably a resting stage formed following sexual fusion) in the life cycle. Of the more than 2000 free-living species that have been documented in the marine realm (Gómez, 2012), around 12-15\%, as a conservative estimate, produce a geologically preservable organic-walled resting cyst (Head, 1996). In contrast to the cells formed during the active life stages of dinoflagellates, these cysts when occurring in the fossil record represent a crucial link to the living dinoflagellate populations and, thus, their contemporary environment. Consequently, cyst assemblages recovered from sedimentary deposits are widely used in the fields of paleoceanography, paleoclimatology, and biostratigraphy. Whereas assemblages tend to be dominated by a number of frequent and fairly widely occurrin'species, less common species can add valuable information because of their often restricted ecologica' constraints and/or stratigraphic ranges.

This review gives a short illustrated description and the lowest itrat graphic occurrence of 22 dinoflagellate cyst species and one informal cyst morphotyp belonging to the order Gonyaulacales, and three dinoflagellate cyst species and one informal cy $c m_{1}$ rphotype belonging to the order Suessiales, with an occasional to rare occurrence or poorly ' ... Jwn record in Upper Pleistocene to recent marine sediments of the Northern Hemispher= The list of taxa illustrated here represents those species present at fewer than 40 locations in . $h \geq n \geq w$ " $n=1968$ " modern surface sediment

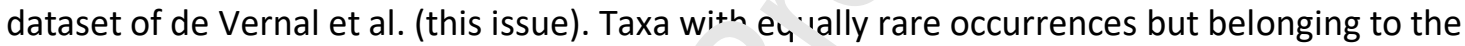
orders Gymnodiniales and Peridiniales are : ' $\mathrm{sCl}$ ssed by Mertens et al. (this issue), and species belonging to the orders Gonyaulacales and Su,_-iales with endemic occurrence in the Black Sea Corridor are discussed by Mudie et al. (20:7). The reader is referred to Van Nieuwenhove et al. (this issue) regarding the understanding of t' 1 e - nncept of "rare species" as used here, while endemism among dinoflagellate cyst species is $\sim^{\prime} \neg b$, $r$,ted by Marret et al. (this issue). A review of extant freshwater dinoflagellate cysts is $\rho_{i}$, on by Mertens et al. (2012).

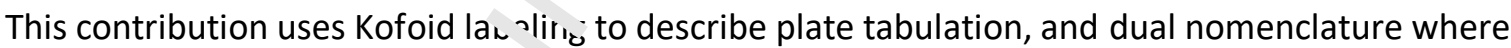
available to link the separate $\iota$ vor omies that have evolved for non-fossil and fossil dinoflagellates (Head et al., 2016).

\section{Systematic part}

Division DINOFLAGELLATA (Bütschli, 1885) Fensome et al., 1993

Class DINOPHYCEAE Pascher, 1914

Subclass PERIDINIPHYCIDAE Fensome et al., 1993

Order GONYAULACALES Taylor, 1980

Suborder GONIODOMINEAE Fensome et al., 1993

Family PYROPHACACEAE Lindemann, 1928 
Comments. The Goniodomataceae Lindemann, 1928 (as Goniodomaceae in Fensome et al., 1993) is a rejected name (Prud'homme van Reine, 2017) following a recommendation by Elbrächter and Gottschling (2015). The Pyrophacaceae is here considered an acceptable substitute.

Subfamily PYRODINIOIDEAE Fensome et al., 1993

\section{Genus Capisocysta Warny and Wrenn, 1997 emend. Head, 1998a \\ Capisocysta lata Head, 1998a}

Plate 1, figs. 1-3

Distinguishing characters. Spheroidal proximate species with a thi. inr ar wall that has a smooth to granulate outer surface and a loosely attached delicate translu :ent suter layer. The outer layer is often lost in dissociated specimens. When lost, the outer lay $r$ ca. occasionally be replaced by small pustules on the surface of the inner wall. Tabulation expr s a unly on the hypocyst, and the individual hypocystal plates are often dissociated as they , re - .l involved in the formation of the hypotractal archeopyle (i.e., an archeopyle that involves che luss of the hypocyst; Head, 1998a). Based on Head (1998a).

Dimensions. Central body diameter 40-56 $\mu^{r} .1$ i lea. 1998a).

Remarks. This species is characterized by its ra. ? acheopyle style (both hypotractal and hypocystal sensu Head, 1998a) in which all of the hy r cystal plates may be lost. When this happens, the remaining hemispheric epicyst can be $r \leq c$. snı right and left sulcal plates and first pnstc $n \varepsilon$ ular plate, that generally remains attached to the epicyst. The derivation of the name Capiso: 'sta ndeed reflects this distinctive epicystal morphology (Warny and Wrenn, 1997). This species is tistir,guished from Capisocysta lyellii Head, 1998a, which is presently known only from the $P_{1}$ incene, by the presence of a single antapical plate (two in Capisocysta lyellii) and less ctro. . I' $y$ ornamented wall.

Biological affinity. Unkı, $w_{1}$.

Lowest stratigraphic occu...ence. Lower Pliocene (Head, 1998a).

Subfamily Helgolandinioideae Fensome et al., 1993

Genus Desotodinium De Schepper et al., 2004

Desotodinium wrennii De Schepper et al., 2004

Plate 1, figs. 4-6

Distinguishing characters. A large, thin-walled proximate species with smooth to shagreenate or scabrate wall surface, and circular to subcircular outline in polar view. Diaphanous equatorial flange with irregular margin may be present. Hypocystal archeopyle comprising three postcingular plates and two antapical plates; otherwise only weak expression of tabulation on hypocyst, and none on epicyst. Based on De Schepper et al. (2004). 
Dimensions. Central body maximum diameter $47-67 \mu \mathrm{m}$ based on Pliocene specimens from Belgium (De Schepper et al., 2004).

Remarks. Desotodinium wrennii was described from the Pliocene of Belgium (De Schepper et al., 2004). Tuberculodinium vancampoae differs in having large barrel-shaped processes that separate the two central body wall layers, and in Capisocysta lata nearly all hypocystal plates are involved in archeopyle formation.

Biological affinity. Probably the cyst of Pyrophacus horologium Stein, 1883 as described by Wall and Dale (1971), according to De Schepper et al. (2004).

Stratigraphic range and distribution. Lower Pliocene through Upper Pleistocene of the Gulf of Mexico (as Forma D in Wrenn and Kokinos, 1986) and modern sediments of Lima, Peru (as cysts of Pyrophacus horologium in Wall and Dale, 1971). To our knowledge, neither Desotodinium wrennii nor the cysts of Pyrophacus horologium have otherwise been repori on from modern sediments.

Suborder GONYAULACINEAE autonym

Family GONYAULACACEAE Lindemann, 1928

Subfamily CRIBROPERIDINIOIDEAE Fensome et al., 1993

Genus Lingulodinium Wall, 1967 emend. Dodge, 985

Lingulodinium hemicystum McMinn, 1991

Plate 2, figs. 1-9

Distinguishing characters. Large tr: $า s p a$, ent to light yellow species with spherical to subspherical central body bearing numerous (, 2 to 30 ) blade-shaped processes. Archeopyle epitractal (all epicystal plates involved in arche nyie formation; Head, 1998a). Processes have a smooth surface, are nontabular, hollow, distally : $?$,ered, each with a circular $~ 3-5 \mu \mathrm{m}$ diameter base. Processes can become bulbous towards their rase. The cyst wall reportedly has a $\sim 1 \mu \mathrm{m}$ thick inner layer with a psilate to finely granulate . 'Irtace, and a thinner, psilate outer layer. The epitractal archeopyle is formed by a splitting of $t$ ' - cyst into two equal halves, which are therefore both found. Tabulation is not otherwise expressed, and only a small sulcal notch or sulcal tab can be seen on better-preserved unfolded specimens. Based on McMinn (1991).

Dimensions. Central body diameter 50-65 $\mu \mathrm{m}$, average process length 5-13 $\mu \mathrm{m}$ (McMinn, 1991).

Remarks. Lingulodinium hemicystum is morphologically very similar to Lingulodinium machaerophorum with which it could be confused during routine counts. Lingulodinium machaerophorum differs in having between one and five precingular plates individually released during archeopyle formation (Wall, 1967). Small spinules or grana on the distal ends of the process, that are typical for Lingulodinium machaerophorum, are not observed on Lingulodinium hemicystum. Lingulodinium brevispinosum Matsuoka and Bujak, 1988 has processes that are shorter and with rounded process tips. No mention is made of striations on the process bases for the type material (McMinn, 1991), but observations from South Korea and the South China Sea suggest faint striations 
on the process bases of some specimens (see, for instance, the specimen illustrated by McMinn, 1992, his plate 2, fig. 15).

Biological affinity. Unknown, but presumably related to Lingulodinium polyedrum given the close similarity of Lingulodinium hemicystum with Lingulodinium machaerophorum.

Lowest stratigraphic occurrence and distribution. Neogene. Lingulodinium hemicystum was described from recent material collected in estuaries of New South Wales, Australia (McMinn, 1991), and reported in late Quaternary (last glacial) sediments from coastal waters of southeastern Australia (McMinn, 1992). Zegarra and Helenes (2011) listed a single occurrence of this species in the Eastern Equatorial Pacific during the Neogene. Lingulodinium hemicystum was also reported from a sediment trap in the western North Pacific and from Holocene samples from the South China Sea (Li et al., 2017, 2018), as well as from estuarine surface sediments of southern South Korea (Pospelova and Kim, 2010, where Lingulodinium hemicystum was grouped toge her with Lingulodinium machaerophorum). In the Atlantic, Lingulodinium hemicystum was ide. ${ }^{+}$ified only by Paredes et al. (2015) in Miocene (and possibly Oligocene) deposits from the Gol' o Sa. Jorge Basin of eastern Patagonia. Lingulodinium hemicystum therefore appears to hav _. sı surter stratigraphic range (Oligocene or Miocene to Holocene) than Lingulodinium machc sor horum (Paleocene-Holocene), as also remarked by L.E. Edwards in Head (1994a, p. 216).

Genus Operculodinium Wall, 1967 emend. Matsuo'.d t.t al., 1997

Operculodinium aguinawense Marret and Kim. 209

Plate 3, figs. 1-6

Distinguishing characters. Subspheroica' tc uvoid central body having a thin wall with a fibroreticulate outer surface and irr ะgu'? rrly spaced processes. Process distribution shows some alignment (e.g. Marret and Kim, 2. J0 s, nl. 3, figs. 1, 4) and is presumably intratabular. The processes are cylindrical, solid with fibrou or $r$, rforated conical bases and about $1 / 3$ of the cyst diameter in length. Process tips are minuz' $v$ a :uleate/multifurcate. Archeopyle is formed by loss of precingular plate $3^{\prime \prime}$. Archeopyle angle s re. tively well defined.

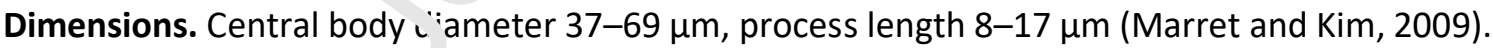

Remarks. Operculodinium aguinawense differs from Operculodinium centrocarpum sensu Wall and Dale, 1966 by its broader cylindrical processes that have fibrous bases. It differs from Operculodinium israelianum Rossignol, 1962 by its smaller size and longer but less numerous processes.

Biological affinity. Unknown.

Lowest stratigraphic occurrence. From at least Marine Isotope Stage (MIS) 5e (Late Pleistocene; Marret and Kim, 2009).

\section{Operculodinium crassum Harland, 1979}

Plate 3, figs. 7-9 
Distinguishing characters. Spherical central body with a relatively thick wall that has a fibroreticulate, "spongy" periphragm and numerous irregularly spaced processes that are probably intratabular in distribution. The processes are conical with minutely expanded distal tips, relatively short (about $1 / 5$ to $1 / 8$ of cyst diameter) and are fibrous. Archeopyle formed by loss of precingular plate $3^{\prime \prime}$. Archeopyle angles are rounded.

Dimensions. Central body maximum diameter 54-74 $\mu \mathrm{m}$, process length 8-17 $\mu \mathrm{m}$ (Harland, 1979).

Remarks. Harland in Head and Wrenn (1992, p. 20) considered Operculodinium crassum a taxonomic junior synonym of Operculodinium israelianum, but both were retained as distinctive species by Head (1996) pending further study of both species. A restudy of topotype material by MJH indicates that the wall thickness of Operculodinium crassum is generally $\sim 1.5-2.0 \mu \mathrm{m}$ rather than the $2.0-4.0$ $\mu \mathrm{m}$ reported by Harland (1979). The range of wall thickness in Operc.' 'ndinium israelianum is not known. Whereas Operculodinium israelianum is known from modf $\mathrm{n}$. ? a ıments (e.g. Limoges et al., 2013), no occurrences postdating the Pleistocene have been repor - ' or Operculodinium crassum. However, its modern-day existence cannot be excluded consid ring its close morphological similarity with the extant species Operculodinium israelianum.

Biological affinity. Unknown.

Lowest stratigraphic occurrence. Upper Miocene of こ:DP Site 400, Bay of Biscay (Harland, 1979) and Lower Miocene of ODP Sites 642 and 643, Norw - sia । Sea (Manum et al., 1989).

\section{Operculodinium giganteum Wall, 1967}

Plate 4, figs. 1-3

Distinguishing characters. Large _ recies with a rounded-polyhedral body that has a spongy/fibroreticulate periphrag.. The numerous processes are short with a conical base and minutely expanded distal ends. T' Julation is intratabular, and alignment of processes can be observed that partially ref, ?cts \& gonyaulacoid tabulation. Archeopyle formed by loss of precingular plate $3^{\prime \prime}$.

Dimensions. Central body diameter 74-86 $\mu \mathrm{m}$, process length 2-4 $\mu \mathrm{m}$ (Wall, 1967).

Biological affinity. Unknown.

Lowest stratigraphic occurrence and distribution. Eocene of India (Sarkar and Singh, 1988). Observed in Holocene sediment of the Caribbean Sea (e.g., Wall, 1967). Operculodinium giganteum was also observed in modern marine sediments of Lake Inkerman, New Brunswick, Canada (I. Aguilar, personal communication).

\section{Operculodinium? longispinigerum Matsuoka, 1983}

Plate 4, figs. 4-7 
Distinguishing characters. Small species having a spherical to subspherical central body with a finely and faintly to moderately granulate surface and sparsely distributed nontabular processes. The processes are nonfibrous, solid, and slender, and long compared to the central body size. Shafts are smooth but may become granulate distally. Processes taper to fine or blunt points, often becoming sinuous distally, or may branch into two or three (rarely four) delicate distal terminations. Different process terminations may occur on the same specimen. Archeopyle precingular, presumably caused by loss of plate 3" (Matsuoka, 1983; Head and Westphal, 1999).

Dimensions. Central body maximum diameter 29-42 $\mu \mathrm{m}$, process length 5-14 $\mu \mathrm{m}$ (Matsuoka, 1983; Head and Westphal, 1999).

Remarks. Head and Westphal (1999) questionably assigned this species to the genus Operculodinium on account of its nonfibrous processes and finely granulate rather than fibroreticulate central body surface. In addition, it differs from Operculodinium centrocarpum se nsu Wall and Dale (1966) by its relatively longer and fewer processes that have acuminate or multifurc ${ }^{+} e$, rather than minutely expanded, distal ends.

Biological affinity. Unknown.

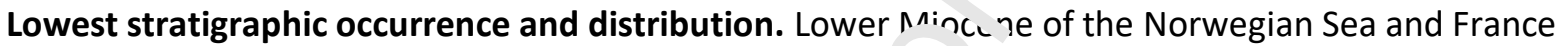
(see Head and Westphal, 1999) and Upper Miocene of Ja, zn ( Matsuoka, 1983). Operculodinium? longispinigerum was observed in modern sediments of $\mathrm{t}^{\prime}$.e Gu'f of Mexico (Limoges et al., 2013).

Subfamily GONYAULACOIDEAE (Autonym)

\section{Genus Achomosphaera Evitt, 1963}

Achomosphaera andalousiensis Jar ¿ ' C..ene, 1977 emend. Jan du Chêne and Londeix, 1988 subsp. andalousiensis (Autonym)

Plate 4, figs. 8-10

Distinguishing characters. Cpıniferate cyst with an ovoidal central body that has a thin wall with a smooth to shagreenate s. wace. Processes are exclusively gonal, and often hollow with a smooth or shagreenate shaft surface. They may have claustra at their base, and terminate distally in characteristic fenestrate platforms. Fenestrations result from branchlets of the bifurcate tips connecting to those of the neighboring bifurcation on the same process. Septa on the central body are lacking, and tabulation is expressed only by process distribution and the precingular archeopyle, formed by loss of plate $3^{\prime \prime}$.

Dimensions. Central body width 34-44 $\mu \mathrm{m}$, central body length $40-50 \mu \mathrm{m}$, process length $14-26 \mu \mathrm{m}$ (Jan du Chêne and Londeix, 1988).

Remarks. Achomosphaera andalousiensis was considered a taxonomic senior synonym of Spiniferites septentrionalis Harland, 1977 by Harland (1983). However, this synonymy was questioned by Head and Wrenn (1992), and not followed by Londeix et al. (2009, p. 67-68; 2018, p. 54) and herein. For comparison with Spiniferites septentrionalis, see remarks thereunder. 
Intraspecific morphotypes. Achomosphaera andalousiensis subsp. suttonensis Head, 1997, described from the Lower Pliocene of eastern England (Head, 1997), has more fenestrations in the distal platforms of the processes, resulting in a perforate appearance. Achomosphaera andalousiensis subsp. suttonensis is not known to range outside of the Pliocene (Louwye et al., 2004).

Biological affinity. Unknown.

Lowest stratigraphic occurrence and distribution. Ambiguity in distinguishing Achomosphaera andalousiensis subsp. andalousiensis from Spiniferites septentrionalis makes it difficult to track the exact stratigraphic record of Achomosphaera andalousiensis andalousiensis from the literature, especially when illustrations are lacking. Following Londeix (2018), the lowest occurrence datum of Achomosphaera andalousiensis andalousiensis appears to be the upper Langhian (Middle Miocene), based on records by Powell (1986) and McCarthy and Mudie (1996), while the Achomosphaera andalousiensis dinozone (Piasecki, 1980), which spans nearly the entıre 'Ipper Miocene, indicates its common abundance during the Late Miocene. The subspecies has its $h$ shest common occurrence in the uppermost Pliocene (Head, 1997; Londeix, 2018) but is onl 1 a. ?ly observed in modern sediments.

\section{Genus Ataxiodinium Reid, 1974}

Ataxiodinium cf. zevenboomii Head, 1997

Plate 5, figs. 1-6

Distinguishing characters. Ovoid cavate _ neci zs with a smooth endoblast and a smooth to faintly granulate periblast. The periblast connec s $s$ vith the endoblast via numerous funnel-shaped invaginations which are unevenly distrı ' 'ted over the cyst surface. Precingular archeopyle.

Dimensions. Endoblast length 32-:1 $\mu \mathrm{m}$, endoblast equatorial diameter 27-34 $\mu \mathrm{m}$, periblast length 34-46 $\mu \mathrm{m}$, periblast equatorinl dia neter 31-38 $\mu \mathrm{m}$, ratio of endoblast length/equatorial diameter 1.1-1.2 (based on new me- un "er. ents by AL on seven specimens from the Baltic Sea).

Remarks. The modern sp -imens illustrated here are ovoidal only and lack the strongly elongate shape of the holotype an + + spotype specimens of Ataxiodinium zevenboomii from the mid-Pliocene of eastern England (Head, 1997).

Biological affinity. Unknown.

Lowest stratigraphic occurrence and distribution. Ataxiodinium cf. zevenboomii has only been recorded from surface sediments of the Baltic Sea (unpublished observation by AL).

Genus Dalella McMinn and Sun, 1994 emend. Zevenboom and Santarelli in Zevenboom, 1995 Dalella chathamensis McMinn and Sun, 1994

Plate 5, figs. 7-12 
Distinguishing characters. Spherical to subspherical central body with a finely granulate surface and conspicuous trabeculae that are connected to the central body at the apex, archeopyle margin, the sulcus, and to the hypocyst in the ventral area only. The trabeculae consist of flat, ribbon-like threads with a thickened central ridge. Archeopyle precingular formed by loss of plate 3".

Dimensions. Central body diameter 18-35 $\mu \mathrm{m}$, total diameter 46-78 $\mu \mathrm{m}$ (McMinn and Sun, 1994).

Remarks. Species of the genus Nematosphaeropsis differ from Dalella chathamensis in having parallel pairs of trabeculate that connect adjacent gonal/intergonal processes distally and do not contact the central body.

Biological affinity. Unknown.

Lowest stratigraphic occurrence and distribution. Isolated rare occurrences in the Upper Pliocene of DSDP Site 610, eastern North Atlantic Ocean (De Schepper and Heac 2009), and occasionally observed in the Holocene (e.g., McMinn and Sun, 1994). Dalella chatha. ?ensis was originally described from, and is more common in, modern sediments of the Sou hern Hemisphere (McMinn and Sun, 1994; Prebble et al., 2013) but has since also been rer or d occasionally from modern sediments of the Northern Hemisphere (Pospelova et al., 20C 8; 2nr.net et al., 2012).

\section{Genus Gonyaulax Diesing, 1866}

Comments. A genus defined by its motile stage.

\section{Cyst of Gonyaulax baltica Ellegaard et al., 200<}

Plate 6, figs. 1-6

Distinguishing characters. Spinif -ate cyst having a spherical to ovoidal central body with a thin, smooth to slightly granular outer vall. Processes are gonal and occasionally intergonal, but can also be lacking over much of the rvs. ''Jhen fully developed, they are hollow and trifid with bifurcate distal tips. Shorter proress 's ot en end bluntly. Septa are low, but higher septa joining the antapical processes are common. A, heopyle precingular formed by loss of plate $3^{\prime \prime}$, rarely also 4".

Dimensions. Central body length 35-49 $\mu \mathrm{m}$, central body width 31-44 $\mu \mathrm{m}$, process length $2-5 \mu \mathrm{m}$ (Ellegaard et al., 2002).

Remarks. The type locality is the Kattegat off the Swedish west coast (southeastern Baltic Sea). Ellegaard et al. (2002) designated a cyst as the holotype, with motile cells belonging to the same strain as the holotype and serving as isotypes also being figured. The diagnosis is based on both motile stage and cyst characters.

Because of their wide morphological variability, some cysts of Gonyaulax baltica may resemble Spiniferites belerius or Spiniferites bulloideus sensu Wall, 1965. Cysts of Gonyaulax baltica generally differ from Spiniferites belerius in lacking a trumpet-shaped antapical process, and from Spiniferites bulloideus sensu Wall, 1965 in having somewhat more robust processes.

Remarks on biological affinity. Incubation experiments and molecular analyses of cysts identified as Impagidinium caspienense Marret et al., 2004 from the Caspian Sea showed that these cysts produce 
motile cells that genetically relate to Gonyaulax baltica (Mertens et al., 2017). It may be that Gonyaulax baltica can produce cysts assignable to two different cyst-based genera, Spiniferites and Impagidinium, likely in response to differing environmental factors, in particular salinity (Mertens et al., 2017). The complete disappearance of processes as observed on the cysts in the Caspian Sea (i.e., Impagidinium caspienense) thus would appear to be the extreme end of a morphological gradation that was partly observed in the Baltic Sea, too, where Gonyaulax baltica including its cyst was first described (Ellegaard et al., 2002).

Lowest stratigraphic occurrence and distribution. Reported from the Upper Holocene (Ellegaard et al., 2002; Mertens et al., 2017; unpublished observations from the Baltic Sea by NVN); with a lowest occurrence in the Upper Pleistocene of the Baltic (Head, 2007).

\section{Genus Impagidinium Stover and Evitt, 1978}

Impaginidinium japonicum Matsuoka, 1983

Plate 7, figs. 1-6

Distinguishing characters. Chorate species with a spheric $\lambda_{1}$, ellipsoidal central body and a finely granulate surface. The tabulation is reflected by well ' ' veloped, finely granulate septa of uniform height. The bases of septa are not cavate. The cinfu. " $m$; displaced two or three times its own width. Archeopyle precingular formed by loss _ " pis ${ }^{+} 3^{\prime \prime}$.

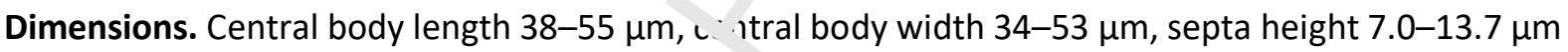
(Matsuoka, 1983).

Remarks. Impagidinium japonicum has $\mathrm{si}^{\prime} \mathrm{n}_{1}{ }^{\prime}-$ rly high septa as Impagidinium strialatum but differs in being larger and having finely granu'u ${ }^{\prime}$ sunta without striations.

Biological affinity. Unknown.

Lowest stratigraphic occurre: re a ad distribution. Pliocene to Lower Pleistocene of central Japan (Matsuoka, 1983) and the .r. $\cdot$ m-Arctic (de Vernal and Mudie, 1989). This species was also documented in modern -e. 'm', nts of the North Atlantic Ocean (Bonnet et al., 2012).

\section{Impagidinium velorum Bujak, 1984}

Plate 7, figs. 7-9

Distinguishing characters. Pale, proximochorate species with an ovoidal central body and smooth to shagrinate surface. The tabulation is reflected by high membranous sutural septa with smooth distal margins. The cingulum is represented by a single septum, and septa border the sulcus. The septa are solid and of uniform height approximating the diameter of the central body, but the septa are often flattened against the central body, obscuring details of tabulation. Archeopyle precingular formed by loss of plate 3". Based on Bujak (1984) and unpublished observations. 
Dimensions. Central body length 17-33 $\mu \mathrm{m}$, central body width 17-28 $\mu \mathrm{m}$, septa height 19-25 $\mu \mathrm{m}$ (Bujak, 1984).

Remarks. Impagidinium velorum differs from Impagidinium pallidum by its smaller central body and much higher sutural septa, and by the cingulum being marked by a single septum only.

Biological affinity. Unknown.

Lowest stratigraphic occurrence and distribution. Middle or Upper Eocene of the North Pacific (Bujak, 1984) and ODP Site 643, Norwegian Sea (Manum et al., 1989). This species was also documented in modern sediments of the North Atlantic Ocean (Bonnet et al., 2012).

Genus Nematosphaeropsis Deflandre and Cookson, 1955 emend. Wrenn, 1988

Nematosphaeropsis rigida Wrenn, 1988

Plate 8 , figs. $1-3$

Distinguishing characters. Chorate to proximochorate $\mathrm{sp}$ !cies having an egg-shaped to slightly elongate central body. The wall is thin $(<1 \mu \mathrm{m})$ and its surfac - is smooth to scabrate. Specimens occasionally show isolated and widely spaced intrat ${ }^{\prime} \sim$ ' 'ar grana. The central body bears solid gonal and (?) intergonal processes that are connected d'st. iv 'y pairs of penitabular trabeculae. The trabecular structure creates a subspherical $c r . .$. ? $_{\mathrm{n}}{ }^{-i c}$ shell around the central body. The bases of the processes are usually perforate and ma, he proximally connected by low ridges. In cross-section, the processes are subrounded to subtriangular, . 'hile the trabeculae appear rounded. Archeopyle precingular formed by loss of precingular p'.'te $3 "$. Based on Wrenn (1988).

Dimensions. Central body length 33-4i| $\mathrm{m}$, central body width $29-39 \mu \mathrm{m}$, overall length $49-72 \mu \mathrm{m}$, overall width $46-73 \mu \mathrm{m}$, process ler gth $\_-7 \mu \mathrm{m}$ (Wrenn, 1988).

Remarks. Nematosphaeropsis rialiv is distinguished from others of the genus by the combination of solid processes and distinctiv ' I v ro ust trabeculae of rounded cross-section. Additionally, the process bases are usually $r$ eri rate and the plates are generally well defined. The superficially similar Nematosphaer,, cis ' $r$, rinthus has a more spherical central body, hollow and relatively longer processes, and trabe ulae that are flattened in cross-section and ribbon-like.

Biological affinity. Unknown.

Lowest stratigraphic occurrence and distribution. Miocene (Wrenn, 1988). Nematosphaeropsis rigida has been observed in modern sediments off Massachusetts, USA (as Nematosphaeropsis balcombiana in Wall and Dale, 1967) and in the Gulf of Mexico (e.g., Limoges et al., 2013).

Genus Spiniferites Mantell, 1850, emend. Sarjeant, 1970

Spiniferites hainanensis Sun and Song, 1992

Plate 8, figs. 4-7 
Distinguishing characters. Central body subspherical to ellipsoidal with a smooth to finely granulate surface. Processes are gonal and intergonal, tapering, and the distally furcate tips may be additionally bifurcate. The processes are fenestrate notably at their base and connected by densely fenestrate moderately high septa. Archeopyle precingular formed by loss of plate $3^{\prime \prime}$.

Dimensions. Central body width 35-42 $\mu \mathrm{m}$, central body length 43-49 $\mu \mathrm{m}$, process length ca. 10.5 $\mu \mathrm{m}$ (Sun and Song, 1992).

Remarks. Spiniferites hyperacanthus differs by its solid rather than perforated sutural septa. Spiniferites multisphaerus differs by its apical protuberance and vesicular central body and processes.

Biological affinity. Unknown.

Lowest stratigraphic occurrence and distribution. Pleistocene (Sun ind Song, 1992). Spiniferites hainanensis was observed in modern sediments from the Gulf of Califo, - ia (Cuellar-Martinez et al., 2018).

Spiniferites multisphaerus Price and Pospelova, 2014

Plate 8 , figs. 8-12

Distinguishing characters. Central body ovoi ad ' $0 \mathrm{r}$ ?ar-shaped. An apical boss is usually present. The thick wall is vesicular, constructed of bu ' $h$ ' $\_$-like elements that continue in the septa and process shafts and give the surface a pit+ed or $r$.iculate appearance. Processes are gonal and occasionally intergonal, with stubby furcate tistal ends. Archeopyle precingular formed by loss of plate $3^{\prime \prime}$.

Dimensions. Central body width $3 C \cdot 51 \mu \mathrm{n}$, central body length (including apical boss), 41-66.5 $\mu \mathrm{m}$, process length 1.5-8 $\mu \mathrm{m}$ (Price a. + Pospelova, 2014; Londeix et al., 2018).

Remarks. Londeix et al. (2018; nlac ed this species in the genus Hafniasphaera Hansen, 1977, as Hafniasphaera multisphae $a, L$ 7sed on the thickness and structure of the vesicular wall, but the species is retained in Sp..ite. * $s$ by Mertens et al. (2018c), Limoges et al. (2018) and herein because of the occurrence of specim „ns with a wall texture intermediate between Hafniasphaera and Spiniferites.

Biological affinity. Unknown.

Lowest stratigraphic occurrence. Upper Pleistocene of the Gulf of California (Price and Pospelova, 2014).

\section{Spiniferites ristingensis Head, 2007}

Plate 9, figs. 1-12

Distinguishing characters. Central body ovoidal with or without apical boss. The central body surface has a minutely bubbly appearance caused by densely distributed blisters and hollow undulations in 
the outer layer of the two-layered cyst wall. The processes are membranous and granulate, and are either truncated or form irregularly polygonal platforms at the distal ends. They are gonal only and joined by sutural crests with a granulate surface. Membranes forming the sutural crests and processes are distinctly bilayered. Archeopyle precingular formed by loss of plate $3 "$.

Dimensions. Central body length 39-49 $\mu \mathrm{m}$, maximum process length 11-17 $\mu \mathrm{m}$ (Head, 2007).

Remarks. Spiniferites delicatus Reid, 1974 has similar processes but higher sutural crests, a reduced archeopyle, and a central body surface that appears more delicately microgranular to microreticulate rather than coarse and bubbly. Spiniferites alaskensis differs in lacking undulations on the surface (for further details, see Marret and Mertens, 2018).

Biological affinity. Unknown.

Lowest stratigraphic occurrence and distribution. Recorded from $\mathrm{s}$. Niments spanning the MiocenePliocene boundary (Popescu et al., 2015) and MIS 5e (Late Pleistocene) i'tead et al., 2005, as Spiniferites sp. 1; Head, 2007). Spiniferites ristingensis is locally ab inda it in modern sediments off Southwestern Portugal (Mertens et al., 2018c). Possibly record : $a$ 1. Jm the Upper Holocene of the Baltic Sea (NVN, unpublished observations).

\section{Spiniferites septentrionalis Harland, 1977}

Plate 10 , figs. $1-3$

Distinguishing characters. Central body ovoidal vith a relatively thick wall and a scabrate to microgranulate surface. Processes are gonai nnly, long and slender, with fenestrate or petaloid distal ends. Tabulation expressed by faint rid je, $c$..d low septa, notably around the archeopyle. Archeopyle precingular formed by liss it prate 3 ".

Dimensions. Central body width : $9-3 \triangleleft \mu \mathrm{m}$, central body length 34-48 $\mu \mathrm{m}$, process length 10-16 $\mu \mathrm{m}$ (Harland, 1977).

Remarks. Spiniferites sept $n t r$, nalis resembles Achomosphaera andalousiensis subsp.

andalousiensis but diffe, $-b_{y}:{ }^{\circ}$ thicker and more granular wall, the presence of ridges and septa, and less well developed fen :strate process tips.

Biological affinity. Unknown.

Lowest stratigraphic occurrence and distribution. The subtleties in distinguishing Spiniferites septentrionalis from Achomosphaera andalousiensis subsp. andalousiensis make it difficult to assess records from the literature, especially when illustrations are lacking. Londeix (2018) accepted a lowest occurrence datum of upper Tortonian or Messinian (Upper Miocene) based on records by Harland (1979), and the species is present in upper Quaternary sediments (Harland, 1977).

Spiniferites septentrionalis disappears in the Middle Pleistocene just before the onset of MIS $5 \mathrm{e}$ in the North Atlantic Bay of Biscay (Penaud et al., 2008) and just before the onset of the Holocene in the Mediterranean Sea (Turon and Londeix, 1988). Its presence in modern sediments is likely but unconfirmed. 


\section{Genus Tectatodinium Wall, 1967 emend. Head, 1994}

\section{Tectatodinium pellitum Wall, 1967 emend. Head, 1994}

Plate 10, figs. 4-9

Distinguishing characters. Subspherical to broadly ovoidal cyst with a thick wall consisting of a thin solid inner layer (pedium) and a thick spongy outer layer (luxuria) of interconnecting, irregular lamellae that rise from a vesicular base and do not fuse or join distally (i.e. a distally open luxuria). The cyst wall appears densely granulo-fibrous under the light microscope. A small apical protuberance is usually present. Archeopyle precingular formed by loss of plate $3^{\prime \prime}$, and typically has well defined angles and an irregular margin.

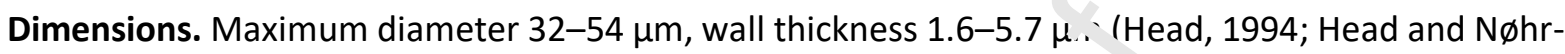
Hansen, 1999).

Biological affinity. Unknown.

Lowest stratigraphic occurrence. Lower Paleocene (Hansen, _.977, as Tectatodinium rugulatum; Head and Nøhr-Hansen, 1999). Pre-Paleocene records of he s secies are considered questionable (Head and Nøhr-Hansen, 1999).

Subfamily UNCERTAIN

Genus Melitasphaeridium Harland and Hill, 1979

Melitasphaeridium angustum Mats'・nka. ‘.983

Plate 11, figs. 1-3

Distinguishing characters. Sma'l proximochorate subspherical species with a coarsely granular surface and somewhat tı 'uuus, slender and hollow intratabular processes with closed acuminate distal tips. Archeopyle proci, igular formed by loss of plate 3 ".

Dimensions. Central body length 33-42 $\mu \mathrm{m}$, central body width $30-37 \mu \mathrm{m}$, process length $9.5-13$ $\mu \mathrm{m}$ (Matsuoka, 1983).

Remarks. According to Matsuoka (1983), Melitasphaeridium angustum is distinguished from Melitasphaeridium choanophorum (Deflandre and Cookson, 1955) Harland and Hill, 1979 by its more granular surface and in having hollow acuminate processes.

Biological affinity. Unknown

Lowest stratigraphic occurrence. Middle Miocene to Pliocene of eastern Japan. As with Melitasphaeridium choanophorum (see below), Melitasphaeridium angustum may also occur in upper Quaternary sediments in specific areas, but records are unconfirmed owing to low abundances and close morphological similarity with Melitasphaeridium choanophorum. 


\section{Melitasphaeridium choanophorum (Deflandre and Cookson, 1955) Harland and Hill, 1979}

Plate 11, figs. 4-11

Distinguishing characters. Spherical central body with a finely granulate surface and rigid to slightly flexuous, hollow tubular processes. The distal tips of the processes are typically flared to form circular platforms with serrated margins, although process tips vary even on the same specimen, with some platforms being significantly reduced in diameter. Archeopyle precingular formed by loss of plate $3^{\prime \prime}$.

Dimensions. Central body 28.0-42.0 $\mu \mathrm{m}$, process length 14.0-21.0 $\mu \mathrm{m}$ (Harland and Hill, 1979). Smaller specimens were recorded by Price et al. (2017): central body 24.6-37.8 $\mu \mathrm{m}$, process length 9.0-14.8 $\mu \mathrm{m}$.

Biological affinity. Unknown.

Lowest stratigraphic occurrence and distribution. Melitasphar riaı 'm choanophorum was originally described from post-Upper Miocene sediments of Australia ( )e i:...dre and Cookson, 1955) and has since been recorded in the Northern Hemisphere from the 2lig cene of Germany (Benedek, 1972), the Lower Miocene and Pliocene of offshore eastern Can Ja I Nilliams, 1975; Williams and Bujak, 1977) and the Lower to Middle Miocene of the offshore vorw :gian-Greenland Sea (Manum, 1976). Late Quaternary records are restricted to the Cariac J F.a. in (Mertens et al., 2009; Bringué et al., 2019), the Gulf of Mexico (Limoges et al., 2014) a-d tric South China Sea (Li et al., 2017).

Melitasphaeridium choanophorum has beer ob: arved in modern sediment from the Gulf of Mexico (Limoges et al., 2013; Price et al., 2017).

Family UNCERTAIN

Genus Pentaplacodinium Merteı- - Carbonell-Moore, Pospelova and Head in Mertens et al., 2018a

Comments. A genus defin $\mathrm{d} b$, its motile stage.

Cyst of Pentaplacodinium saltonense Mertens, Carbonell-Moore, Pospelova and Head in Mertens et al., 2018a

Plate 12, figs. 1-9

Distinguishing characters. Spherical central body with a thick wall consisting of a thin smooth pedium and a thicker spongy-fibrous luxuria appearing loosely granular in surface view. The numerous processes are irregularly spaced suggesting intratabular distribution, except for occasional alignment along the cingular margins. They are solid and fibrous along their entire length with an expanded base and usually minutely expanded, but sometimes tapering distal ends. Closely spaced processes can be joined at the base, and shorter and thinner processes can be interspersed between the dominating longer processes. The archeopyle is relatively wide and reflects the precingular thecal plate * $\left(3^{\prime \prime}+4{ }^{\prime \prime}\right)$ or both plates 2 " and * $\left(3^{\prime \prime}+4{ }^{\prime \prime}\right)$. 
Dimensions. Central body diameter 46-71 $\mu \mathrm{m}$, process length 1.0-5.7 $\mu \mathrm{m}$, wall thickness 0.9-2.4 $\mu \mathrm{m}$ (Mertens et al., 2018a).

Remarks. Operculodinium israelianum has a narrower archeopyle and may have longer processes than the cyst of Pentaplacodinium saltonense. Operculodinium centrocarpum sensu Wall and Dale, 1966 (= the cyst of Protoceratium reticulatum (Claparède and Lachmann, 1859) Bütschli, 1885) has a smaller central body, a narrower archeopyle, lacks a thick spongy-fibrous luxuria, and its processes have more pronounced distal expansions.

Biological affinity. Germination experiments link this cyst to the motile stage of Pentaplacodinium saltonense (Mertens et al., 2018a). Ceratocorys mariaovidiorum Salgado et al., 2018 is a junior synonym of the dinoflagellate Pentaplacodinium saltonense (see Mertens et al., 2018b). Mertens et al. (2018a) and Salgado et al. (2018) show that Pentaplacodinium saltonense had until then erroneously been identified as Protoceratium reticulatum (Claparèc' ? and Lachmann, 1859) Bütschli, 1885 (al. Gonyaulax grindleyi Reinecke, 1967).

Lowest stratigraphic occurrence. Upper Cenozoic (Mertens et al <n1ca).

\section{Suborder UNCERTAIN}

Family UNCERTAIN

\section{Genus Dapsilidinium Bujak et al., 1980}

Dapsilidinium pastielsii (Davey and Williams, 1sj6) Bujak et al., 1980

Plate 12 , figs. $10-12$

Distinguishing characters. Large $\iota$ 'orate species with a spheroidal central body and finely granulate surface. The intratabular, fairly ev nly spaced hollow processes with a granulate surface taper distally to a narrow neck bef $\sim$ re $:$...panding minutely to an opening with a serrated or irregular margin. Two or three F"oc sses may be fused along most of their length. Process bases usually have elongate claustra that may 're more pronounced where processes are fused. Archeopyle formed by loss of the four apical plaıs, operculum free.

Dimensions. Central body diameter 37-56 $\mu \mathrm{m}$, process length $8.5-18.0 \mu \mathrm{m}$ (this study).

Remarks. Dapsilidinium pseudocolligerum (Stover, 1977) Bujak et al., 1980 described from the Oligocene of the eastern United States shelf, was formerly differentiated from Dapsilidinium pastielsii by its longer and more widely spaced processes with narrower bases (Stover, 1977), but additional measurements by Mertens et al. (2014, their supplemental figure DR2) reveal that these parameters do not distinguish these species unambiguously. Hence, Mertens et al. (2014) considered Dapsilidinium pseudocolligerum a junior synonym of Dapsilidinium pastielsii, a judgement followed here.

Biological affinity. Undescribed dinoflagellate closely related to the hystrichokolpomoid lineage and placed within the subfamily Cribroperidinioideae (Mertens et al., 2014). 
Lowest stratigraphic occurrence and distribution. Lower Paleocene (Brinkhuis and Schiøler, 1996), possibly Campanian or Maastrichtian (e.g., Marheinecke, 1992), and thought to have become extinct in the Early Pleistocene (Head and Westphal, 1999) until living cysts were recorded by Mertens et al. (2014) in surface sediments of the western central Pacific Ocean.

Order SUESSIALES Fensome et al., 1993

Family SUESSIACEAE Fensome et al., 1993

\section{Genus Biecheleria Moestrup et al., 2009}

Comments. A genus defined by its motile stage.

Cyst of Biecheleria baltica Moestrup et al., 2009

Plate 12 , figs. $1-7$

Distinguishing characters. Spherical cyst with a hyal it wall covered by densely and evenly spaced processes. Process length varies from very short $v \leq r_{1} \quad r=$-like protrusions to simple rods a few $\mu \mathrm{m}$ long. The nature of the archeopyle is unknov .1, 'uu -necimens illustrated here superficially suggest an epitractal archeopyle.

Dimensions. Central body diameter 20-s? um (Kremp et al., 2005).

Remarks. The motile cells that product $t^{t} \cdot e: \_$cysts were originally identified from Baltic Sea material by Kremp et al. (2005) as Gymnodin ur. hulophilum Biecheler, 1952 which they then transferred to the genus Woloszynskia Thompsc I, + 751 as Woloszynskia halophila (Biecheler, 1952) Kremp et al., 2005. However, Moestrup et al. (2 ( ר) considered the Baltic specimens described by Kremp et al. (2005) as distinct from Gymn c dinic in halophilum, and assigned them to a new species Biecheleria baltica, while transferring 'sec'eler's Gymnodinium halophilum to Biecheleria halophila.

Lowest stratigraphic occur : ence. At least the Upper Holocene of the Baltic Sea (unpublished observations by NVN).

\section{Cyst of cf. Biecheleria baltica Moestrup et al., 2009}

Plate 12 , figs. 8-11

Remarks. Cysts appearing very similar to Biecheleria baltica have been found in Holocene sediments and sediment trap samples from numerous Arctic and temperate regions (Price and Pospelova, 2011; Bringué et al., 2013; Heikkilä et al., 2014, 2016; Limoges et al., 2018; unpublished observations by AR in the Beaufort Sea and Canadian Arctic Archipelago). These authors noted a central body diameter between 8 and $30 \mu \mathrm{m}$ and a process length between 0.5 and $3 \mu \mathrm{m}$ for these (sub)arctic specimens. They are identified in the literature as "cyst of cf. Biecheleria baltica" or "cyst of cf. 
Biecheleria sp.", and here referred to as cf. Biecheleria baltica pending more information on the cyst-theca relationship for these arctic specimens.

\section{Cyst of Biecheleria cincta (Siano et al., 2009) Balzano et al., 2012}

See Siano et al. (2009) and Luo et al. (2013) for rare illustrations of this cyst.

Distinguishing characters. Small spherical cyst with a brown to dark wall covered with small grains and numerous short $(0.5-1.0 \mu \mathrm{m})$ columnar spines. Some spines can be distally capitate. A faint tabulation pattern probably reflecting the position of the amphiesmal vesicles of the vegetative cell is present on the surface of the cyst. The archeopyle is small and circular.

Dimensions. Central body diameter 10-17 $\mu \mathrm{m}$ (Siano et al., 2009; Lu'o et al., 2013).

Remarks. The cyst has presently been observed only in cultures est-hlisı. ?d from surface seawater (Siano et al., 2009) and coastal surface sediment samples (Luo et a . 2( 13). The full stratigraphic range of the cyst is undocumented.

\section{Genus Polarella Montresor et al., 1999}

Comments. A genus defined by its motile stage.

\section{Cyst of Polarella glacialis Montresor et al., : ar y}

Plate 12 , figs. $12-19$

Distinguishing characters. Small spiny y Al $_{1}$, e cyst with an elongated, rounded-cylindrical to characteristically "peanut-shaped" $r$ oci: I ne body wall is smooth, but faint lines can sometimes be observed reflecting plate bounda: ies. 'ntratabular, plate-centered acicular processes reflect the tabulation except in the cingulu $n, v$.here processes are absent. Processes are needle-shaped (acicular), each tapering with : wic e base and a straight to slightly concave shaft ending in a pointed distal tip. The nature of th ar heopyle is unknown.

Dimensions. Central body . 'idth 8-15 $\mu \mathrm{m}$, central body length 12-17 $\mu \mathrm{m}$, process length $2.7-4.2 \mu \mathrm{m}$ (Montresor et al., 1999).

Lowest stratigraphic occurrence. At least MIS 3 (Upper Pleistocene) (unpublished observations by AL and NVN; Stijn De Schepper, personal communication November 2018).

\section{Acknowledgements}

We are most grateful to Marianne Ellegaard, Sofia Ribeiro, Fabienne Marret, Jan A.I. Hennissen, Aurélie Penaud and Frédérique Eynaud for providing pictures or palynological slides. AL, MJH and VP acknowledge financial support from their respective Natural Sciences and Engineering Research Council of Canada Discovery Grants. Editor-in-chief Richard Jordan and two anonymous reviewers are thanked for their valuable comments and suggestions. 


\section{Plate Captions}

Plate 1 1-3. Capisocysta lata, the holotype from the Pliocene of eastern England (Head, 1998) in (1) bright field, (2) interference contrast and (3) phase contrast. 4-6. Desotodinium wrennii, specimen from the Pleistocene (Olduvai Subchron) of the western North Atlantic (DSDP Hole 603C). High to low focus, apical view, showing the ps plate at the top, the two antapical plates below, and three postcingular plates below these. All images by $\mathrm{MJH}$. All scale bars $=10 \mu \mathrm{m}$.

Plate 2 1-9. Lingulodinium hemicystum. 1-2. High and low focus of specimen from the Pacific Ocean. 3, 6. High and low focus of specimen from surface sediments offshore Qingdao (China). 4. High focus of another specimen from Omura Bay (Japan) surface sediments. 5. Optical section of specimen with cell content from the same locality. 7-9. High to low focus at slightly different orientations of specimen from the same locality. Images $1-2$ by VP, 3-9 by KNM. All scale bars $=10 \mu \mathrm{m}$.

Plate 3 1-6. Operculodinium aguinawense. 1-3. High to low focus, a ral view, of a topotype from the Gulf of Guinea. 4-6. High to low focus, antapical view, of anoth - + oputype from the Gulf of Guinea. 7-9. Operculodinium crassum, topotype from the Bay of $B_{1}-$ ra' (DSDP Leg 48, Hole 400A), seen in (7) high focus and (8-9) optical section at two slightly $c$ ffer nt focal depths. Images 1-6 by NVN (slide provided by Fabienne Marret, 7-9 by MJH. All sci 0 baıs $=10 \mu \mathrm{m}$.

Plate 4 1-3. Operculodinium giganteum, high to low foct of s secimen from Inkerman Lake, Pokemouche River estuary (New Brunswick, Canada) surface -ediments. 4-7. Operculodinium longispinigerum. 4-5. Specimen from the Gulf of $\mathrm{Mr}$ xir 0 6-7. High focus and optical section of a different specimen from the Gulf of Mexico. 8-10. Ac.--nosphaera andalousiensis subsp. andalousiensis from the Gulf of Mexico (ODF Le; $1 \mathrm{~L}^{\prime}$, Site 625b). 8. High focus on fenestrate distal ends of processes. 9. Lower focus on the do _ .' surface of the cyst. 10. Optical section. Image 1-3 by AR, $4-7$ by $A L, 8-10$ by KNM.

Plate 5 1-6. Ataxiodinium cf. zevenboo $\mathrm{nI}$, ${ }^{+}$wo spcimens at high to low focus from the Baltic Sea. 712. Dalella chathamensis. 7-9. High $+n$ lo $\%$ ocus on specimen from MIS $5 e$ at the Challenger Plateau, off New Zealand (DSDP Site 593). 1i Specimen from the South Indian Ocean (core MD12-3396). 1112. Different focal depths of a diti rent specimen from the same locality. Image 1-3 by NVN, 4-6 by AL, 7-9 by Fabienne Marret, 10- ? $^{?}$ by Frédérique Eynaud. All scale bars $=10 \mu \mathrm{m}$.

Plate 6 1-6. Cyst of Gonya ılax ' 'altica. 1-3. High to low focus, dorsal view, of specimen from Limfjord (Denmark). 4-6. 4ly:. co low focus of specimen with cell content from Langden Station, Tvärminne (Gulf of Finland) jurface sediments. All images by KNM. All scale bars $=10 \mu \mathrm{m}$.

Plate 7 1-6. Impagidinium japonicum. 1-6. New micrographs of the holotype (Matsuoka, 1983). High to low focus, dorsal view. 7-9. Impagidinium velorum, specimen from the latest Pliocene of the central North Atlantic Ocean (IODP Hole U1313C; from Hennissen, 2013). 7. Focus on the microgranulate wall of the central body. 8. Optical section. 9. Focus on the sutural crests. 1-6 by $\mathrm{MJH}, 7-9$ by Jan A.I. Hennissen. All scale bars $=10 \mu \mathrm{m}$.

Plate 8 1-3. Nematosphaeropsis rigida. 1-2. Optical section and low focus on specimen from the Gulf of Mexico (Limoges et al., 2013). 3. Optical section of a different specimen from the same locality. 4-7. Spiniferites hainanensis from Southern China surface sediments. 4-6. Increasing focal depth, dorsal view. 7. Oblique dorso-lateral view of the hypocyst. 8-12. Spiniferites multisphaerus. 8-9. Optical section and low focus on specimen from the Pacific Ocean. 10-12. Different focal depths of a different specimen from the Pacific Ocean. Image 1-3 by AL, 4-7 by KNM, 8-12 by VP. All scale bars $=10 \mu \mathrm{m}$. 
Plate 9 1-12. Spiniferites ristingensis, specimens from (sub)surface sediments off Portugal (core PO287-39B, Ribeiro et al., 2016). 1-3. High to low focus, apical view. 4-6. High to low focus, dorsal view. 7-8. High and mid-focus, dorso-lateral view. 9-12. High to low focus, oblique antapical view. All images by KNM. All scale bars $=10 \mu \mathrm{m}$.

Plate 10 1-3. Spiniferits septentrionalis, three specimens from MIS 6 in the Bay of Biscay (core MD03-2692, Penaud et al., 2008). 4-9. Tectatodinium pellitum from the eastern Mediterranean Sea. 4-6. High to low focus, ventro-lateral view. 7-8. High focus and optical section of a different specimen. 9. Optical section of another specimen. Image 1-3 by Aurélie Penaud, 4-9 by KNM. All scale bars $=10 \mu \mathrm{m}$.

Plate 11 1-3. Melitasphaeridium angustum, new micrographs of the holotype (Matsuoka, 1983). Apical view in (1) high focus and (2-3) optical section at two slightly different focal depths. 4-11. Melitasphaeridium choanophorum from the Gulf of Mexico. 4-6. Hi, h to low focus. 7, 11. Different focal depths of different specimen. 8-10. High to low focus of another s, ecimen. Image 1-3 by KNM, $4-11$ by AL. All scale bars $=10 \mu \mathrm{m}$.

Plate 12 1-9. Cyst of Pentaplacodinium saltonense from Salton Sea California, USA) surface sediments. 1-3. High to low focus, dorsal view. 4-5. High foc s and optical section of a different specimen. 6, 9. High focus and optical section of a differe it $s_{1}$ ecimen. 7-8. High focus and optical section of another specimen. 10-12. Dapsilidinium pastiels." inree different specimens from the Phillippines. All images by KNM. All scale bars $=10 \mu \mathrm{m}$.

Plate 13 1-7. Cyst of Biecheleria baltica from the lialtı sea (core KSK12-01D). 1-2. Optical section and low focus of specimen with cell content 3-. . Hish focus showing the (?) archeopyle, and low focus, of a different specimen. 5-7. High to $\mathrm{l}$ - focal view of another specimen suggesting an epicystal archeopyle. 8-11. Cyst of cf. Bi-cheleria baltica. 8-9. High focus and optical section of specimen with cell content from the Arr: $r_{.}$? -11 . High focus and optical section of specimen with cell content from NE Greenland. 12-15. r ys : of Polarella glacialis. 12. Optical section of specimen from the Arctic. 13-15. High to low ocu- of specimen from northern Baffin Bay. 16-17. Different focal depths of a specimen with rill a ntent from northern Baffin Bay. 18-19. Different focal depths of specimen with cell content fr $m$ ci:e Wandel Sea. Image $1-7,13-17$ by NVN, 8-9, 12 by VP, 10$11,18-19$ by AL. All scale bars $-10 \mu \mathrm{m}$.

\section{References}

Balzano, S., Gourvil, S., Siano, R., Chanoine, M., Marie, D., Lessard, S., Sarno, D., Vaulot, D., 2012.

Diversity of cultured photosynthetic flagellates in the northeast Pacific and Arctic Oceans in summer. Biogeosciences 9, 4553-4571.

Benedek, P.N., 1972. Phytoplanktonten aus dem Mittel- und Oberoligozän von Tönisberg (Niederrheingebiet). Palaeontographica Abteilung B 137, 1-71.

Biecheler, B., 1952. Recherches sur les Péridiniens. Bulletin Biologique de la France et de la Belgique 36 (suppl.), 1-149.

Bonnet, S., de Vernal, A., Gersonde, R., Lembke-Jene, L., 2012. Modern distribution of dinocysts from the North Pacific Ocean $\left(37-64^{\circ} \mathrm{N}, 144^{\circ} \mathrm{E}-148^{\circ} \mathrm{W}\right)$ in relation to hydrographic conditions, sea-ice and productivity. Marine Micropaleontology 84-85, 87-113. 
Bringué, M., Pospelova, V., Pak, D., 2013. Seasonal production of organic-walled dinoflagellate cysts in an upwelling system: a sediment trap study from the Santa Barbara Basin, California. Marine Micropaleontology 100, 34-51.

Bringué, M., Pospelova, V., Tappa, E.J., Thunell, R.C., 2019. Dinoflagellate cyst production in the Cariaco Basin: a 12.5 year-long sediment trap study. Progress in Oceanography 171, 175-211. doi:10.1016/j.pocean.2018.12.007.

Brinkhuis, H., Schiøler, P., 1996. Palynology of the Geulhemmerberg Cretaceous/Tertiary boundary section (Limburg, SE Netherlands). In: Brinkhuis, H., Smit, J. (eds.), The Geulhemmerberg Cretaceous/Tertiary Boundary Section (Maastrichtian Type Area, SE Netherlands). Netherlands, Kluwer, p. 193-213.

Bujak, J.P., 1980. Dinoflagellate cysts and acritarchs from the Eocene Barton Beds of southern England. In: Bujak, J.P., Downie, C., Eaton, G.L., Williams, G.L. (eds.), Dinoflagellate cysts and acritarchs from the Eocene of southern England. The Palaeontologiral A_-ociation, Special Papers in Palaeontology 24, 36-91.

Bujak, J.P., 1984. Cenozoic dinoflagellate cysts and acritarchs fi jm t ie Bering Sea and northern North Pacific, DSDP Leg 19. Micropaleontology 30, 180-212.

Bujak, J.P., Downie, C., Eaton, G.L., Williams, G.L., 1980. ['nofı ıgellate cysts and acritarchs from the Eocene of southern England. The Palaeontological Associ tic.' Special Papers in Palaeontology 24, 36-91.

Bütschli, O., 1885. 3. Unterabtheilung (Ordnuno) ₹ inotlagellata. In: Dr. H.G. Bronn's Klassen und Ordnungen des Thier-Reichs, wissenschaftli .n d rgestellt in Wort und Bild. Erster Band Protozoa. C.F. Wintersche Verlagshandlung, Leipzig und ' 'oidelberg, pp. 906-1029.

Claparède, E., Lachmann, J., 1859. Études su r les Infusoires et les rhizopodes. Mémoires de l'Institut national genevois 6, 261-482.

Cuellar-Martinez, T., Alonso-Rodrígılez, ? , Ruiz-Fernández, A.C., de Vernal, A., Morquecho, L., Limoges, A., Henry, M., Sanchez-r abe $\_$, J.-A., 2018. Environmental forcing on the flux of organicwalled dinoflagellate cysts in recint _ediments from a subtropical lagoon in the Gulf of California. Science of the Total Environmt. $t f 21,548-557$.

Davey, R.J., Williams, C '., : 96f. V. The genus Hystrichosphaeridium and its allies. In: Davey, R.J., Downie, C., Sarjeant, W.A.v Williams, G.L. (eds.), Studies on Mesozoic and Cainozoic dinoflagellate cysts. British Museum (Na ural History) Geology, Bulletin, Supplement 3, 53-106.

Deflandre, G, Cookson, I.C., 1955. Fossil microplankton from Australian Late Mesozoic and Tertiary sediments. Australian Journal of Marine and Freshwater Research 6, 242-313.

De Schepper, S., Head, M.J., 2009. Pliocene and Pleistocene dinoflagellate cyst and acritarch zonation of DSDP Hole 610a, Eastern North Atlantic. Palynology 33, 179-218.

De Schepper, S., Head, M.J., Louwye, S. 2004. New dinoflagellate cyst and incertae sedis taxa from the Pliocene of northern Belgium, southern North Sea Basin. Journal of Paleontology 78, 625-644.

de Vernal, A., Radi, T., Zaragosi, S., Allan, E., Eynaud, F., Head, M.J., Limoges, A., Londeix, L., Marret, F., Matthiessen, J., Penaud, A., Pospelova, V., Price, A., Richerol, T., Rochon, A., Van Nieuwenhove, N., this issue. The distribution of common modern dinoflagellate cyst taxa in surface sediment of the Northern Hemisphere in relation to environmental parameters: the new $n=1968$ database. Marine Micropaleontology. 
de Vernal, A., Mudie, P.J., 1989. Pliocene and Pleistocene palynostratigraphy at ODP Sites 646 and 647, eastern and southern Labrador Sea. In: Srivastava, S.P., Arthur, M., Clement, B., et al., Proceedings of the Ocean Drilling Program, Scientific Results, 105. Ocean Drilling Program, College Station, Texas, p. 401-422.

Diesing, C.M., 1866. Revision der Prothelminthen, Abtheilung: Mastigophoren. Akademie der Wissenschaften zu Wien, Sitzungsberichte, Mathematisch-naturwissenschaftliche Klasse 52(8), 287401.

Dodge, J.D., 1989. Some revisions of the family Gonyaulacaceae (Dinophyceae) based on scanning electron microscope study. Botanica Marina 32, 275-298.

Elbrächter, M., Gottschling, M., 2015. (2383) Proposal to reject the name Goniodomataceae (Dinophyceae). Taxon 64, 1052-1053.

Ellegaard, M., Lewis, J., Harding, I., 2002. Cyst-theca relationship, life $c^{-1}{ }^{-1}$, and effects of temperature and salinity on the cyst morphology of Gonyaulax ba tica p. nov. (Dinophyceae) from the Baltic Sea area. Journal of Phycology 38, 775-789.

Evitt, W.R., 1963. A discussion and proposals concerning fos- I dlıurlagellates, hystrichospheres, and acritarchs, I. National Academy of Sciences, Washington, r i : e tings 49, 158-164.

Fensome, R.A., Taylor, F.J.R., Norris, G., Sarjeant, W.A.S., 'Nı. rton, D.I., Williams, G.L., 1993. A classification of living and fossil dinoflagellates. Micr us leontology Special Publications 7, 1-351.

Gómez, F., 2012. A quantitative review of the life. vle, nabitat and trophic diversity of dinoflagellates (Dinoflagellata, Alveolata). Systematics and sior versity 10, 267-275.

Hansen, J.M., 1977. Dinoflagellate stratisraphy a. d echinoid distribution in Upper Maastrichtian and Danian deposits from Denmark. Bulletin nt ¿'e Geological Society of Denmark 26, 1-26.

Harland, R., 1977. Recent and Late O' 'att rr ary (Flandrian and Devensian) dinoflagellate cysts from marine continental shelf sediments arouıd the British Isles. Palaeontographica Abteilung B 164, p. 87-126.

Harland, R., 1979. Dinoflagell +e bu stratigraphy of Neogene and Quaternary sediments at holes 400/400A in the Bay of Bis .ay 'Deep Sea Drilling Project Leg 48). In: Montadert, L. et al. (eds.), Deep Sea Drilling Project, Wa_ hir, ${ }^{+r}$. I, Initial Reports 48, 531-545.

Harland, R., 1983. Distrib +t; un maps of Recent dinoflagellate cysts in bottom sediments from the North Atlantic Ocean and adjacent seas. Palaeontology 26, 321-387.

Harland, R., Hill, J., 1979. A reappraisal of the Cainozoic dinoflagellate cyst "Hystrichosphaeridium" choanophorum Deflandre et Cookson 1955. Review of Palaeobotany and Palynology 28, 37-45.

Head, M.J., 1994a (Editor). A forum on Neogene and Quaternary dinoflagellate cysts: The edited transcript of a round table discussion held at the Third Workshop on Neogene and Quaternary Dinoflagellates; with taxonomic appendix. Palynology 17, 201-239 [Imprinted 1993].

Head, M.J., 1994b. Morphology and paleoenvironmental significance of the Cenozoic dinoflagellate genera Tectatodinium and Habibacysta. Micropaleontolology 40, 289-321.

Head, M.J., 1996. Late Cenozoic dinoflagellates from the Royal Society borehole in Ludham, Norfolk, eastern England. Journal of Paleontology 70, 543-570. 
Head, M.J., 1997. Thermophilic dinoflagellate assemblages from the Mid Pliocene of Eastern England. Journal of Paleontology 71, 165-193.

Head, M.J., 1998a. New Goniodomacean dinoflagellates with a compound hypotractal archeopyle from the Late Cenozoic. Capisocysta Warny and Wrenn, emend. Journal of Paleontology 72, 797809.

Head, M.J., 1998b. Pollen and dinoflagellates from the Red Crag at Walton-on-the-Naze, Essex: evidence for a mild climatic phase during the early Late Pliocene of eastern England. Geological Magazine 135, 803-817.

Head, M.J., 2007. Last Interglacial (Eemian) hydrographic conditions in the southwestern Baltic Sea based on dinoflagellate cysts from Ristinge Klint, Denmark. Geological Magazine 144, 987-1013.

Head, M.J., Nøhr-Hansen, H., 1999. The extant thermophilic Tectatodinium pellitum (al. Tectatodinium rugulatum) from the Danian of Denmark. Journal of $P$ : : ontology $73,577-579$.

Head, M.J., Westphal, H., 1999. Palynology and paleoenvironment : of c Pliocene carbonate platform: The Clino Core, Bahamas. Journal of Paleontology 73 - ' b.

Head, M.J., Wrenn, J.H., 1992. Neogene and Quaternary din $\cap$ flageilate cysts and acritarchs. American Association of Stratigraphic Palynologists Found au $n$, Dallas, 438pp.

Head, M.J., Fensome, R.A., Herendeen, P.S., Skog, J.E., 2016. 315-319) Proposals to amend Article 11.8 and its Examples to remove ambiguity in the sa $心$ oning of dual nomenclature for dinoflagellates, and an emendation of Article 11.7 E, am ple 29. Taxon 65, 902-903.

Head, M.J., Seidenkrantz, M.-S., Janczyk-Kor .kol /a, L., Marks, L., Gibbard, P.L., 2005. Last interglacial (Eemian) hydrographic conditions in the soutı, 'astern Baltic Sea, NE Europe, based on dinoflagellate cysts. Quaternary International 130, 3-3̌

Heikkilä, M., Pospelova, V., Hochheim, ..F ., Kuzyk, Z.Z.A., Stern, G.A., Barber, D.G., Macdonald, R.W., 2014. Surface sediment dinoflagella+ $-r_{-}{ }^{\star}$, from the Hudson Bay system and their relation to freshwater and nutrient cycling. $M_{a}$. ine Micropaleontology 106, 79-109.

Heikkilä, M., Pospelova, V., Fore-t, r., Stern, G.A., Fortier, L., Macdonald, R.W. 2016. Dinoflagellate cyst production over an annuc' cyc'e in seasonally ice-covered Hudson Bay. Marine Micropaleontology 125, 1- 24.

Hennissen, J., 2013. Late r." xcene-Early Pleistocene North Atlantic circulation: integrating dinocyst assemblages and foramir. ${ }^{\circ}$ - ral geochemistry, Department of Earth Sciences. University of Toronto, Unpublished PhD Thesis, 258pp. http://hdl.handle.net/1807/35845.

Jan du Chêne, R., 1977. Étude palynologique du Miocène supérieur Andalou (Espagne). Revista española de micropaleontología 9, 97-114.

Jan du Chêne, R., Londeix, L., 1988. Données nouvelles sur Achomosphaera andalousiense Jan du Chêne, 1977, kyste de dinoflagellé fossile. Bulletin des Centres de recherches exploration-production Elf-Aquitaine 12, 237-250.

Kremp, A., Elbrächter, M., Schweikert, M., Wolny, J.L., Gottschling, M., 2005. Woloszynskia halophila (Biecheler) comb. nov.: a bloom-forming cold-water dinoflagellate co-occurring with Scrippsiella hangoei (Dinophyceae) in the Baltic Sea. Journal of Phycology 41, 629-642.

Li, Z., Pospelova, V., Liu, L., Zhou, R., Song, B., 2017. High-resolution palynological record of Holocene climatic and oceanographic changes in the northern South China Sea. Palaeogeography, Palaeoclimatology, Palaeoecology 483, 94-124. 
Li, Z., Pospelova, V., Lin, H.-L., Liu, L., Song, B., Gong, W., 2018. Seasonal dinoflagellate cyst production and terrestrial palynomorph deposition in the monsoon influenced South China Sea: A sediment trap study from the Southwest Taiwan waters. Review of Palaeobotany and Palynology 257, 117-139.

Limoges, A., Londeix, L., de Vernal, A., 2013. Organic-walled dinoflagellate cyst distribution in the Gulf of Mexico. Marine Micropaleontology 102, 51-68.

Limoges, A., de Vernal, A., Van Nieuwenhove, N., 2014. Long-term hydrological changes in the northeastern Gulf of Mexico (ODP-625B) during the Holocene and late Pleistocene inferred from organic-walled dinoflagellate cysts. Palaeogeography, Palaeoclimatology, Palaeoecology 414, 178191.

Limoges, A., Ribeiro, S., Weckström, K., Heikkilä, M., Zamelczyk, K., Andersen, T.J., Tallberg, P., Massé, G., Rysgaard, S., Nørgaard-Pedersen, N., Seidenkrantz, M.-S., 2018. Linking the modern distribution of biogenic proxies in High Arctic Greenland shelf sedimonts to sea ice, primary production and Arctic-Atlantic inflow. Journal of Geophysical Rese rrch: Biogeosciences 123, https://doi.org/10.1002/2017JG003840.

Lindemann, E., 1928. Abteilung Peridineae (Dinoflagellatae). n: Engler, A., Prantl, K. (eds.), Die Natürlichen Pflanzenfamilien nebst ihren Gattungen und vicı ' igeren Arten insbesondere den Nutzpflanzen. Zweite stark vermehrte und verbesserte Aui ${ }^{-}$¿e herausgegeben von A. Engler. 2 Band. Leipzig, Wilhelm Engelmann, pp. 3-104.

Londeix, L., 2018. Quantitative biostratigraphical $r n_{5}=$ of some late Cenozoic species of the dinoflagellate genus Spiniferites and taxonor IIC ons. derations. Palynology 42 suppl. 1, 203-220.

Londeix, L., Zonneveld, K., Masure, E., 2018. 1a. 'nnomy and operational identification of Quaternary species of Spiniferites and related genera. Dalynology 42 Suppl. 1, 45-71.

Louwye, S., Head, M.J., De Schepper, S $2 \mathrm{x}^{\prime}$. Dinoflagellate cyst stratigraphy and palaeoecology of the Pliocene in northern Belgium, sr u he $e_{1}$ North Sea Basin. Geological Magazine 141, 353-378.

Luo, Z., Yang, W., Xu, B., Gu, H., 2'113. .irst record of Biecheleria cincta (Dinophyceae) from Chinese coasts, with morphological and 1. nlt iular characterization of the strains. Chinese Journal of Oceanology and Limnology 31, $235-845$.

Mantell, G.A., 1850. A . ict rial ttlas of Fossil Remains Consisting of Coloured Illustrations Selected from Parkinson's "Organic ' emains of a Former World", and Artis's "Antediluvian Phytology". Henry G. Bohn, London, U.K., xil. <07 pp.

Manum, S.B., 1976. Dinocysts in Tertiary Norwegian-Greenland Sea sediments (Deep Sea Drilling Project Leg 38), with observations on palynomorphs and palynodebris in relation to environment. In: Talwani, M., Udintsev, G. (eds), Initial Reports DSDP, 38. US Government Printing Office, Washington, 897-919.

Manum, S.B., Boulter, M.C., Gunnarsdottir, H., Rangnes, K., Scholze, A., 1989. Eocene to Miocene palynology of the Norwegian Sea (ODP Leg 104). In: Eldholm, O., Thiede, J., Taylor, E., et al. (Eds.), Proceedings of the Ocean Drilling Program, Scientific Results 104, College Station, TX, p. 611-662.

Marheinecke, U., 1992. Monographie der Dinozysten, Acritarcha und Chlorophyta des Maastrichtium von Hemmoor (Niedersachsen). Paleontographica Abteilung B 227, 1-173. 
Marret, F., Kim, S.-Y., 2009. Operculodinium aguinawense sp. nov., a dinoflagellate cyst from the Late Pleistocene and recent sediments of the east equatorial Atlantic Ocean. Palynology 33, 125139.

Marret, F., Mertens, K.N., 2018. Additional observations of Spiniferites alaskensis from topotype material. Palynology 42 (S1), 89-92.

Marret, F., Bradley, L, de Vernal, A., Hardy, W., Kim, S.-Y., Mudie, P., Penaud, A., Pospelova, V., Price, A.M., Radi, T., Rochon, A., this issue. From bi-polar to regional distribution of modern dinoflagellate cysts, an overview of their biogeography. Marine Micropaleontology.

Marret, F., Leroy, S., Chalié, F., Gasse, F., 2004. New organic-walled dinoflagellate cysts from recent sediments of central Asian seas. Review of Palaeobotany and Palynology 129, 1-20.

Matsuoka, K., 1983. Late Cenozoic dinoflagellates and acritarchs in the Niigata district, central Japan. Palaeontographica Abteilung B 187, 89-154.

Matsuoka, K., Bujak, J.P., 1988. Cenozoic dinoflagellate cysts from the I avarin Basin, Norton Sound and St. George Basin, Bering Sea. Nagasaki University, Faculty ci Li' 'eral Arts, Natural Science, Bulletin 29 (1), 1-147.

Matsuoka, K., McMinn, A., Wrenn, J.H., 1997. Restudy of t'it 'oı, 'otype of Operculodinium centrocarpum (Deflandre and Cookson) Wall (Dinophycea!! fr sm the Miocene of Australia, and the taxonomy of related species. Palynology $21,19-33$.

McCarthy, F.M.G., Mudie, P.J., 1996. Palynology a id ¿in Jflagellate biostratigraphy of Upper Cenozoic sediments from Sites 898 and 900, ot ia r.hyssal Plain. In: Whitmarsh, R.B., Sawyer, D.S., Klaus, A., et al. (eds.), Proceedings of the Oce ${ }^{\prime}$. Drilling Program, Scientific Results, 149. Ocean Drilling Program, College Station, Texas, ?41-26:.

McMinn, A., 1991. Recent dinoflagellat _ c, ts from estuaries on the central coast of New South Wales, Australia. Micropaleontology 27, . '6'j-287.

McMinn, A., 1992. Recent and lat : $u_{\text {: }}$ 'ternary dinoflagellate cyst distribution on the continental shelf and slope of southeastern Aus'ralia. Palynology 16, 13-24.

McMinn, A., Sun, X., 1994. Rect $1+$ dinoflagellate cysts from the Chatham Rise, Southern Ocean, east of New Zealand. Palynnlog /18. 41-53.

Mertens, K.N., Carbonell-N, ore, M.C., Pospelova, V., Head, M.J., Highfield, A., Schroeder, D., Gu, H., Andree, K.B., Fernandez, Ivı., Yamaguchi, A., Takano, Y., Matsuoka, K., Nézan, E., Bilien, G., Okolodkov, Y., Koike, K., Hoppenrath, M., Pfaff, M., Pitcher, G., Al-Muftah, A., Rochon, A., Lim, P.T., Leaw, C.P., Lim, Z.F., Ellegaard, M., 2018a. Pentaplacodinium saltonense gen. et sp. nov. (Dinophyceae) and its relationship to the cyst-defined genus Operculodinium and yessotoxinproducing Protoceratium reticulatum. Harmful Algae 71, 57-77.

Mertens, K.N., Carbonell-Moore, M.C., Pospelova, V., Head, M.J., 2018b. Ceratocorys mariaovidiorum P.Salgado, S.Fraga, F.Rodríguez, P.Riobó \& I.Bravo is a junior synonym of Pentaplacodinium saltonense K.N.Mertens, M.C.Carbonell-Moore, V.Pospelova \& M.J.Head. Notulae algarum 45, 1-2.

Mertens, K.N., González, C., Delusina, I., Louwye, S., 2009. 30000 years of productivity and salinity variations in the late Quaternary Cariaco Basin revealed by dinoflagellate cysts. Boreas 38, 647-662.

Mertens, K.N., Gu, H., Gurdebeke, P.R., Takano, Y., Clarke, D., Aydin, H., Li, Z., Pospelova, V., Matsuoka, K., Head, M.J., this issue. A review of rare and endemic extant marine organic-walled 
dinoflagellate cyst taxa of the orders Gymnodiniales and Peridiniales from the Northern Hemisphere. Marine Micropaleontology.

Mertens, K.N., Rengefors, K., Moestrup, $\varnothing$., Ellegaard, M. 2012. A review of recent freshwater dinoflagellate cysts: taxonomy, phylogeny, ecology and palaeocology. Phycologia 51, 612-619.

Mertens, K., Takano, Y., Gu, H., Bagheri, S., Pospelova, V., Pieńkowski, A.J., Leroy, S.A.G., Matsuoka, K., 2017. Cyst-theca relationship and phylogenetic position of Impagidinium caspienense incubated from Caspian Sea surface sediments: relation to Gonyaulax baltica and evidence for heterospory within Gonyaulacoid dinoflagellates. Journal of Eukaryotic Microbiology 64, 82-842.

Mertens, K.N., Takano, Y., Head, M.J., Matsuoka, K., 2014. Living fossils in the Indo-Pacific warm pool: A refuge for thermophilic dinoflagellates during glaciations. Geology 42, 531-534.

Mertens, K.N., Van Nieuwenhove, N., Gurdebeke, P.R., Aydin, H., Bogus, K., Bringué, M., Dale, B., De Schepper, S., de Vernal, A., Ellegaard, M., Grothe, A., Gu, H., Head, N .' Heikkilä, M., Limoges, A., Londeix, L., Louwye, S., Marret, F., Masure, E., Matsuoka, K., Mudi., r. '., Penaud, A., Pospelova, V., Price, A.M., Ribeiro, S., Rochon, A., Sangiorgi, F., Schreck, M., Torre., V , Uzar, S., Versteegh, G.J.M., Warny, S., Zonneveld, K., 2018c. The dinoflagellate cyst genera Achı mosphaera Evitt 1963 and Spiniferites Mantell 1850 in Pliocene to modern sediments: a summary of round table discussions. Palynology 42 suppl. 1, 10-44.

Moestrup, $\varnothing$., Lindberg, K., Daugbjerg, N., 2009. Studies r n v loszynskioid dinoflagellates IV: The genus Biecheleria gen. nov. Phycological Research 5, J3-220.

Montresor, M., Procaccini, G., Stoecker, D.K., 195: Polarella glacialis, gen. nov., sp. nov. (Dinophyceae): Suessiaceae are still alive! Jr urn .l of Phycology 35, 186-197.

Mudie, P.J., Marret, F., Mertens, K.N., Shumilovs.ikh, L., Leroy, S.A.G., 2017. Atlas of modern dinoflagellate cyst distributions in the Blacn Sea Corridor: from Aegean to Aral Seas, including Marmara, Black, Azov and Caspian Sea . M/lc .ne Micropaleontology 134, 1-152.

Paredes, J.M., Foix, N., Guerstein, G R., E' 'xler, V., Irigoyen, M., Moscoso, P., Giordano, S. 2015. A late eocene-early Oligocene transgre ' sive svent in the Golfo San Jorge basin: Palynological results and stratigraphic implications. Journc' ol Jouth American Earth Sciences 63, 293-309.

Pascher, A., 1914. Über Flar,_"’ıı.। und Algen. Deutsche Botanische Gesellschaft, Berichte 32, 136160.

Penaud, A., Eynaud, F., Turc ı, J.L., Zaragosi, S., Marret, F., Bourillet, J.F., 2008. Interglacial variability (MIS 5 and MIS 7) and dinoflagellate cyst assemblages in the Bay of Biscay (North Atlantic). Marine Micropaleontology 68, 136-155.

Piasecki, S., 1980. Dinoflagellate cyst stratigraphy of the Miocene Hodde and Gram Formations, Denmark. Geological Society of Denmark Bulletin 29, 53-76.

Popescu, S.-M., Dalibard, M., Suc, J.-P., Barhoun, N., Melinte-Dobrinescu, M.-C., Bassetti, M.A., Deaconu, F., Head, M.J., Gorini, C., Do Couto, D., Rubino, J.-L., Auxietre, J.-L., Floodpage, J., 2015. Lago Mare episodes around the Messinian-Zanclean boundary in the deep southwestern Mediterranean. Marine and Petroleum Geology 66, 55-70.

Pospelova, V., Kim, S.J., 2010. Dinoflagellate cysts in recent sediments from the aquaculture sites of southern South Korea. Marine Micropaleontology 76, 37-51. 
Pospelova, V., de Vernal, A., Pedersen, T.F., 2008. Distribution of dinoflagellate cysts in surface sediments from the northeastern Pacific Ocean $\left(43-25^{\circ} \mathrm{N}\right)$ in relation to sea-surface temperature, salinity, productivity and coastal upwelling. Marine Micropaleontology 68, 21-48.

Powell, A.J., 1986. A dinoflagellate cyst biozonation for the Late Oligocene to Middle Miocene succession of the Langhe Region, northwest Italy. American Association of Stratigraphic Palynologists Contributions Series 17, 105-127.

Prebble, J.G., Crouch, E.M., Carter, L., Cortese, G., Bostock, H., Neil, H., 2013. An expanded modern dinoflagellate cyst dataset for the Southwest Pacific and Southern Hemisphere with environmental associations. Marine Micropaleontology 101, 33-48.

Price, A.M., Pospelova, V., 2011. High-resolution sediment trap study of organic-walled dinoflagellate cyst production and biogenic silica flux in Saanich Inlet (BC, Canada). Marine Micropaleontology 80, 18-43.

Price, A.M., Pospelova, V., 2014. Spiniferites multisphaerus, a new Alr flagellate cyst from the Late Quaternary of the Guaymas Basin, Gulf of California, Mexico. Palvnn' 'n’y 38, 101-116.

Price, A.M., Baustian, M.M., Turner, E., Rabalais, N.N., Chmur $3, \leqslant 1$, 2017. Melitasphaeridium choanophorum - a living fossil dinoflagellate cyst in the Gulf o. Mexico. Palynology 41, 351-358.

Prud'homme van Reine, W.F., 2017. Report of the Nomern' 'at'،re Committee for Algae: 15. Taxon 66, 191-192.

Reid, P.C., 1974. Gonyaulacacean dinoflagellate c) st. rr . $n$ the British Isles. Nova Hedwigia 25, 579637.

Reinecke, P., 1967. Gonyaulax grindleyi sp. nov - a dinoflagellate causing a red tide at Elands Bay, Cape Province, in December 1966. Journa' of South African Botany 33, 157-160.

Ribeiro, S., Amorim, A., Abrantes, F., El ə̧ ac. d, M., 2016. Environmental change in the Western Iberia Upwelling Ecosystem since th $\approx \sim-e_{\text {II }}$ dustrial period revealed by dinoflagellate cyst records. The Holocene 26, 874-889.

Rossignol, M., 1962. Analyse polı, 'que de sédiments marins quaternaires en Israël II. - Sédiments pleistocènes. Pollen et Spornc 4, 121-148.

Salgado, P., Fraga, S., Ro 'rígu_L, F., Bravo, I., 2018. Ceratocorys mariaovidiorum sp. nov. (Gonyaulacales), a new dinc flagellate species previously reported as Protoceratium reticulatum. Journal of Phycology 54, 126-137.

Sarjeant, W.A.S., 1970. The genus Spiniferites Mantell, 1850 (Dinophyceae). Grana 10, 74-78.

Sarkar, S., Singh, H.P., 1988. Palynological investigation of the Subathu Formation (Eocene) in the Banethi-Bagthan area of Himachal Pradesh, India. Palaeontographica, Abteilung B 209, 29-109.

Siano, R., Kooistra, W.H.C.F., Montresor, M., Zingone, A., 2009. Unarmoured and thin-walled dinoflagellates from the Gulf of Naples, with the description of Woloszynskia cincta sp. nov. (Dinophyceae, Suessiales). Phycologia 48, 44-65.

Stein F.v., 1883. Der Organismus der Infusionsthiere. 3. Abt. Der Organismus der Arthrodelen Flagellaten nach eigenen Forschungen in systematischer Reihenfolge bearbeitet. 2. Hälfte. Einleitung und Erklärung der Abbildungen. W. Engelmann, Leipzig, pp. 30. 
Stover, L.E., 1977. Oligocene and Early Miocene dinoflagellates from Atlantic Corehole 5/5B, Blake Plateau. American Association of Stratigraphic Palynologists, Contributions Series 5A, 66-89.

Stover, L.E., Evitt, W.R., 1978. Analyses of pre-Pleistocene organic-walled dinoflagellates. Stanford University Publications, Geological Sciences 15, 300 pp.

Sun, X., Song, Z., 1992. Quaternary dinoflagellates from arenaceous dolomite in Hainan Island. Acta Micropalaeontologica Sinica 9, 45-52.

Taylor, F.J.R., 1980. On dinoflagellate evolution. BioSystems 13, 65-108.

Thompson, R.H., 1951. A new genus and new species of fresh-water Pyrrophyta in the Desmokontae and Dinophyceae. Lloydia 13, 277-299.

Turon, J.-L., Londeix, L., 1988. Les assemblages de kystes de dinoflagellés en Méditerranée occidentale (Mer d'Alboran). Mise en évidence de l'évolution des pa,' senvironnements depuis le dernier maximum glaciaire. Bulletin des Centres de Recherches Exr'.u. '尹tı n-Production Elf-Aquitaine $12,313-344$.

Van Nieuwenhove, N., Pospelova, V., de Vernal, A., Rochon, $f$., his ssue. Preface: A historical perspective on the development of the Northern Hemisphere nodern dinoflagellate cyst database. Marine Micropaleontology.

Wall, D., 1965. Modern hystrichospheres and dinoflaraliate cysts from the Woods Hole region. Grana 6, 297-314.

Wall, D., 1967. Fossil microplankton in deep sea corc; from the Caribbean Sea. Palaeontology 10, 95-123.

Wall, D., Dale, B., 1966. Living fossils in we-tern Atlantic plankton. Nature 211, 1025-1026.

Wall, D., Dale, B., 1967. The resting cy: ts of , nodern marine dinoflagellates and their palaeontologcal significance. Revie v c. Palaeobotany and Palynology 2, 349-354.

Wall, D., Dale, B., 1971. A recons, 'eratıon of living and fossil Pyrophacus von Stein, 1883 (Dinophyceae). Journal of Phycolc 'v 7, 221-235.

Warny, S.A., Wrenn, J.H., 1 yy; New species of dinoflagellate cysts from the Bou Regreg core: a Miocene-Pliocene bour, ${ }^{\mathrm{J}} \mathrm{ar}$, ' $c$ ction on the Atlantic coast of Morocco. Review of Palaeobotany and Palynology 96, 281-304.

Williams, G.L., 1975. Dinoflagellate and spore stratigraphy of the Mesozoic-Cenozoic, offshore eastern Canada. Geological Survey of Canada, Paper 74-30, v.2, 107-161.

Williams, G.L., Bujak, J.P., 1977. Cenozoic palynostratigraphy of offshore Eastern Canada. American Association of Stratigraphic Palynologists Foundation, Contribution Series 5A, 13-65.

Williams, G.L., Fensome, R.A., MacRae, R.A., 2017. DINOFLAJ3. American Association of Stratigraphic Palynologists, Data Series no. 2. http://dinoflaj.smu.ca/dinoflaj3.

Wrenn, J.H., 1988. Differentiating species of the dinoflagellate cyst genus Nematosphaeropsis Deflandre and Cookson 1955. Palynology 12, 129-150.

Wrenn, J. H., Kokinos, J.P., 1986. Preliminary comments on Miocene through Pleistocene dinoflagellate cysts from De Soto Canyon, Gulf of Mexico. In: J. H. Wrenn, S. L. Duffield, and J. A. Stein (eds.), Papers from the First Symposium on Neogene Dinoflagellate Cyst Biostratigraphy. American Association of Stratigraphic Palynologists Contributions Series 17, 169-225. 
Zegarra, M, Helenes, J. 2011. Changes in Miocene through Pleistocene dinoflagellates from the Eastern Equatorial Pacific (ODP Site 1039), in relation to primary productivity. Marine Micropaleontology 81, 107-121.

Zevenboom, D., 1995. Dinoflagellate cysts from the Mediterranean Late Oligocene and Miocene. Ph.D. Thesis, University of Utrecht, pp. 221.

Zonneveld, K.A.F., Marret, F., Versteegh, G.J.M., Bogus, K., Bonnet, S., Bouimetarhan, I., Crouch, E., de Vernal, A., Elshanawany, R., Edwards, L., Esper, O., Forke, S., Grøsfjeld, K., Henry, M., Holzwarth, U., Kielt, J.-F., Kim, S.-Y., Ladouceur, S., Ledu, D., Chen, L., Limoges, A., Londeix, L., Lu, S.-H., Mahmoud, M.S., Marino, G., Matsouka [sic], K., Matthiessen, J., Mildenhal [sic], D.C., Mudie, P., Neil, H.L., Pospelova, V., Qi, Y., Radi, T., Richerol, T., Rochon, A., Sangiorgi, F., Solignac, S., Turon, J.-L., Verleye, T., Wang, Y., Wang, Z., Young, M., 2013. Atlas of modern dinoflagellate cyst distribution based on 2405 data points. Review of Palaeobotany and Palynology 191, 1-197. 


\section{Highlights}

- 25 rare or endemic extant dinoflagellate cyst species and two morphotypes are briefly described and illustrated

- 23 belong to the Gonyaulacales and 4 to the Suessiales

- their stratigraphic ranges are provided 


\section{Declaration of Interest}

This revised version of our manuscript was approved by all authors and we collectively have no conflict of interest to declare. 


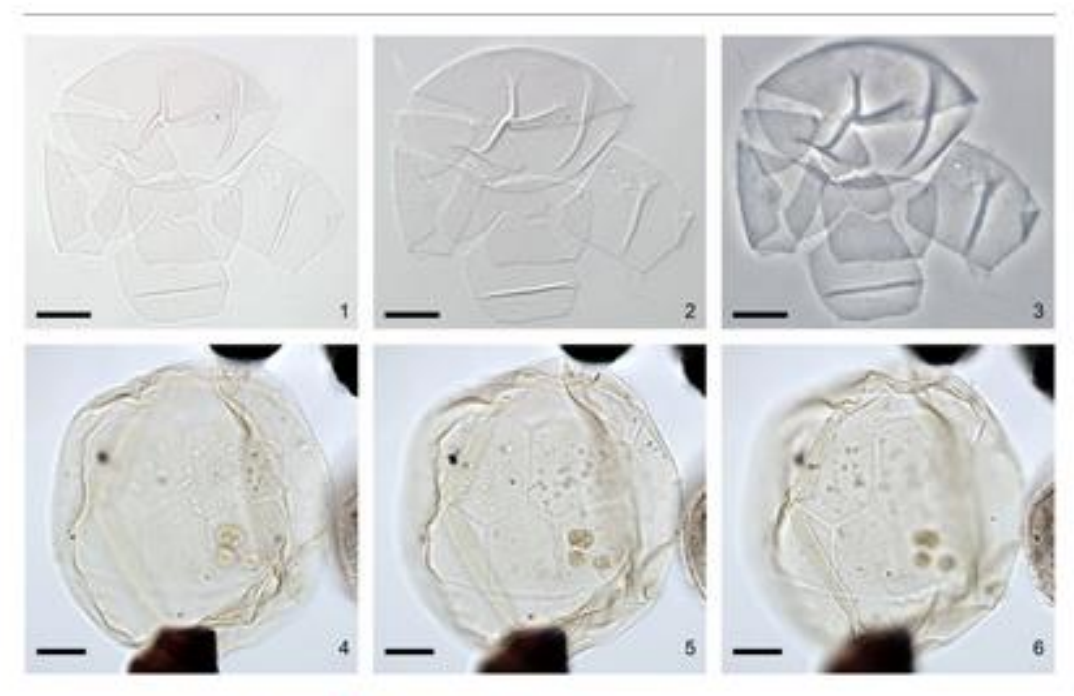

Download : Download high-res image (2MB)

Download : Download full-size image

Plate 1.1-3. Capisocysta lata, the holotype from the Pliocene of eastern England (Head, 1998a, Head, 1998b) in (1) bright field, (2) interference contrast and (3) phase contrast. 4-6. Desotodinium wrennii, specimen from the Pleistocene (Olduvai Subchron) of the western North Atlantic (DSDP Hole 603C). High to low focus, apical view, showing the ps plate at the top, the two antapical plates below, and three postcingular plates below these. All images by MJH. All scale bars $=10 \mu \mathrm{m}$. 

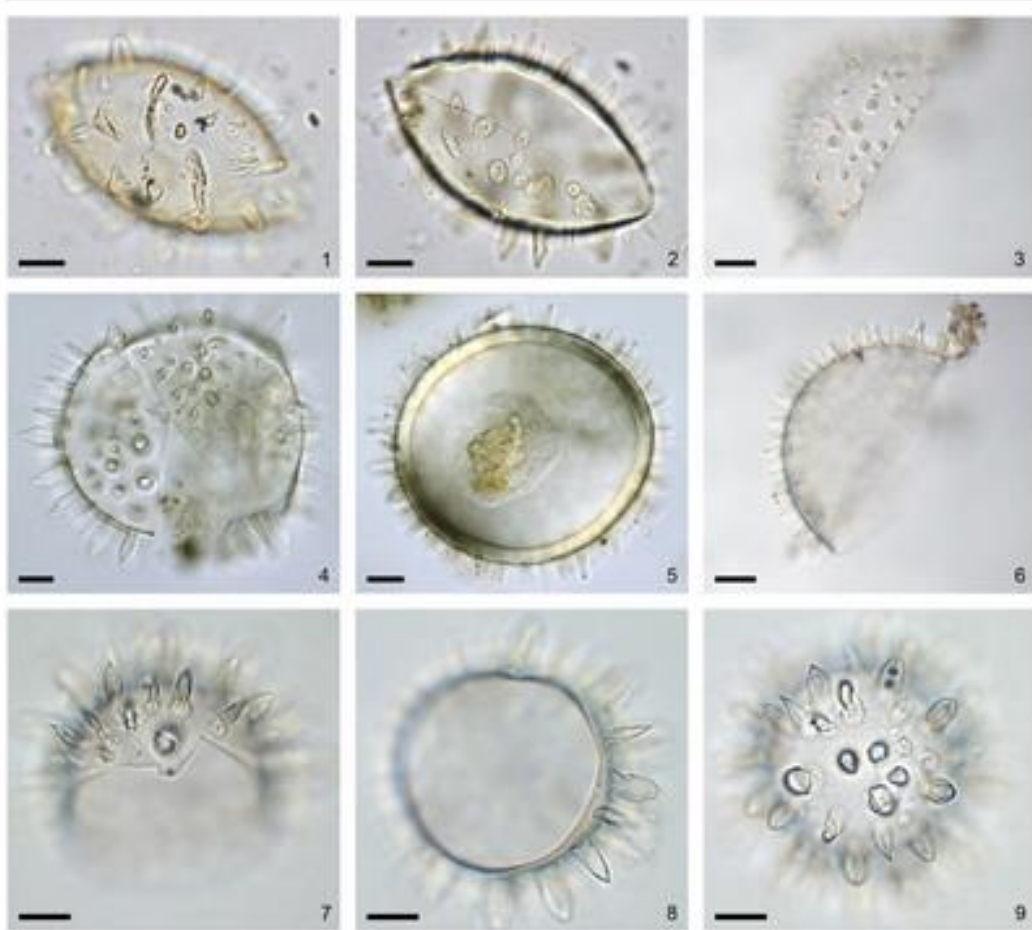

Download : Download high-res image (2MB)

Download : Download full-size image

Plate 2. 1-9. Lingulodinium hemicystum. 1-2. High and low focus of specimen from the Pacific Ocean. 3, 6. High and low focus of specimen from surface sediments offshore Qingdao (China). 4. High focus of another specimen from Omura Bay (Japan) surface sediments. 5.

Optical section of specimen with cell content from the same locality. 7-9. High to low focus at slightly different orientations of specimen from the same locality. Images $1-2$ by VP, 3-9 by KNM. All scale bars $=10 \mu \mathrm{m}$. 

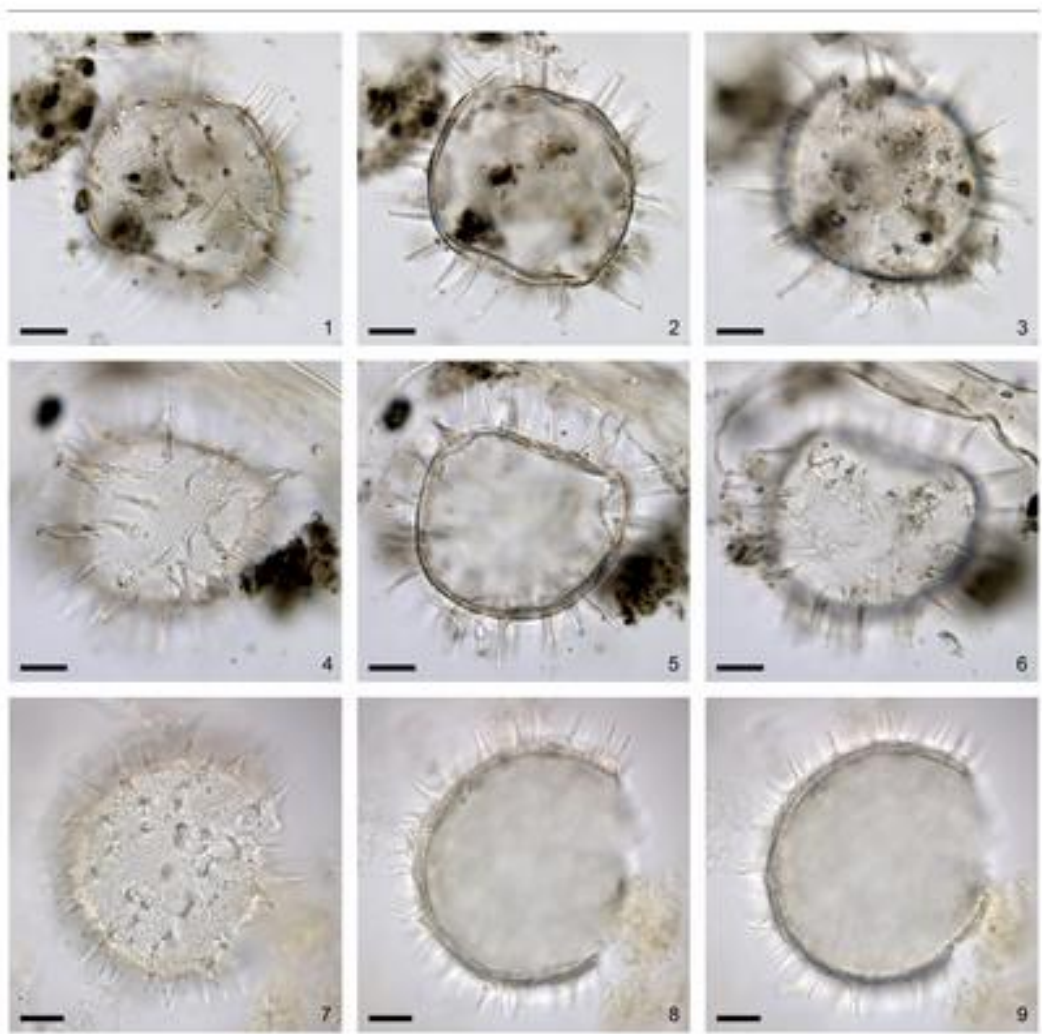

Download : Download high-res image (3MB)

Download : Download full-size image

Plate 3. 1-6. Operculodinium aguinawense. 1-3. High to low focus, apical view, of a topotype from the Gulf of Guinea. 4-6. High to low focus, antapical view, of another topotype from the Gulf of Guinea. 7-9. Operculodinium crassum, topotype from the Bay of Biscay (DSDP Leg 48, Hole 400A), seen in (7) high focus and (8-9) optical section at two slightly different focal depths. Images 1-6 by NVN (slide provided by Fabienne Marret, 7-9 by MJH. All scale bars $=10 \mu \mathrm{m}$. 

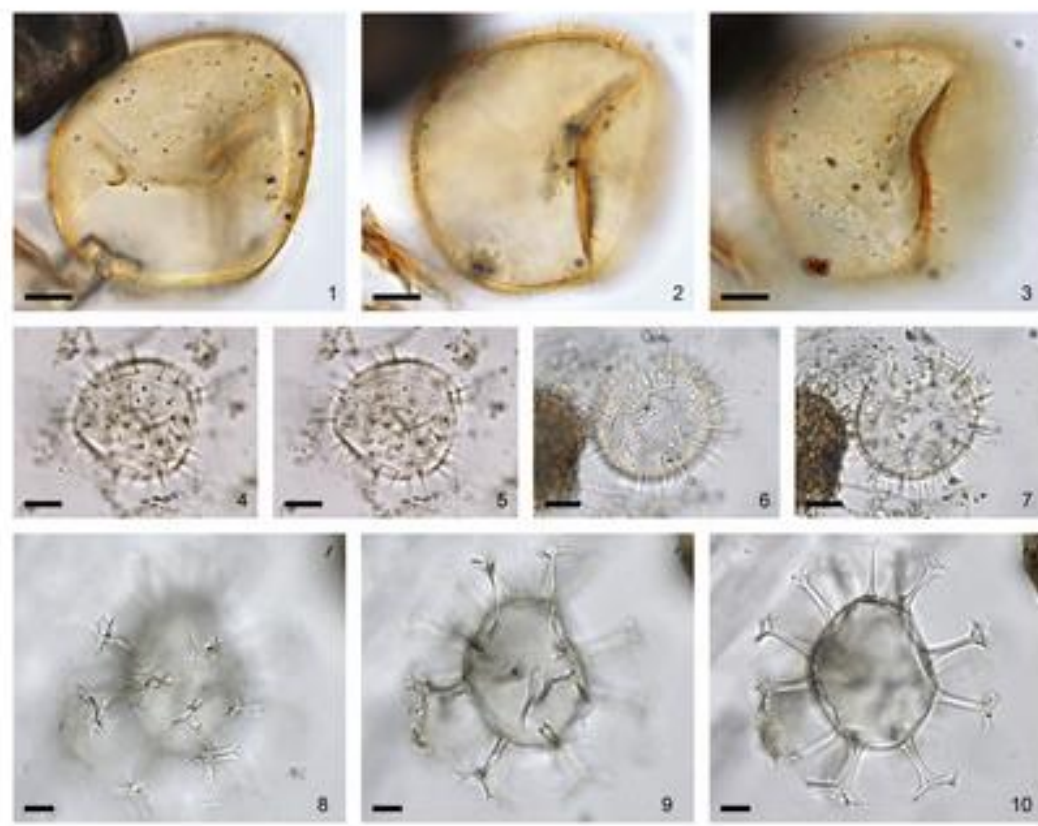

Download : Download high-res image (3MB)

Download : Download full-size image

Plate 4. 1-3. Operculodinium giganteum, high to low focus of specimen from Inkerman Lake, Pokemouche River estuary (New Brunswick, Canada) surface sediments. 4-7. Operculodinium longispinigerum. 4-5. Specimen from the Gulf of Mexico. 6-7. High focus and optical section of a different specimen from the Gulf of Mexico. 8-10. Achomosphaera andalousiensis subsp. andalousiensis from the Gulf of Mexico (ODP Leg 100 , Site $625 \mathrm{~b}$ ). 8 . High focus on fenestrate distal ends of processes. 9. Lower focus on the dorsal surface of the cyst. 10. Optical section. Image $1-3$ by AR, $4-7$ by AL, $8-10$ by KNM. 

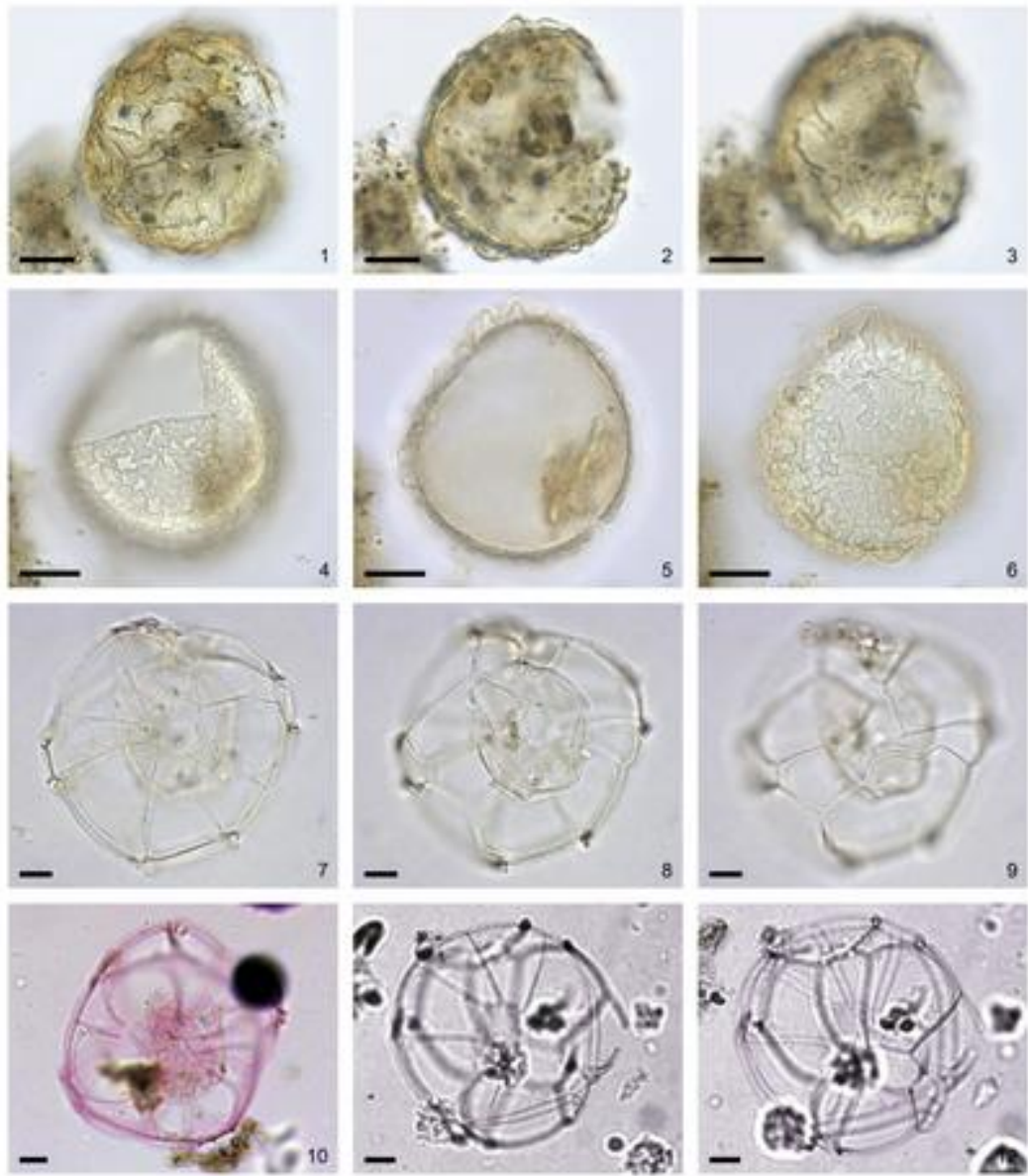

Download : Download high-res image (4MB)

Download : Download full-size image

Plate 5.1-6. Ataxiodinium cf. zevenboomin, two spcimens at high to low focus from the Baltic Sea. 7-12. Dalella chathamensis. 7-9. High to low focus on specimen from MIS $5 e$ at the Challenger Plateau, off New Zealand (DSDP Site 593). 10. Specimen from the South Indian Ocean (core MD12-3396). 11-12. Different focal depths of a different specimen from the same locality. Image $1-3$ by NVN, $4-6$ by AL, 7-9 by Fabienne Marret, $10-12$ by Frédérique Eynaud. All scale bars $=10 \mu \mathrm{m}$. 

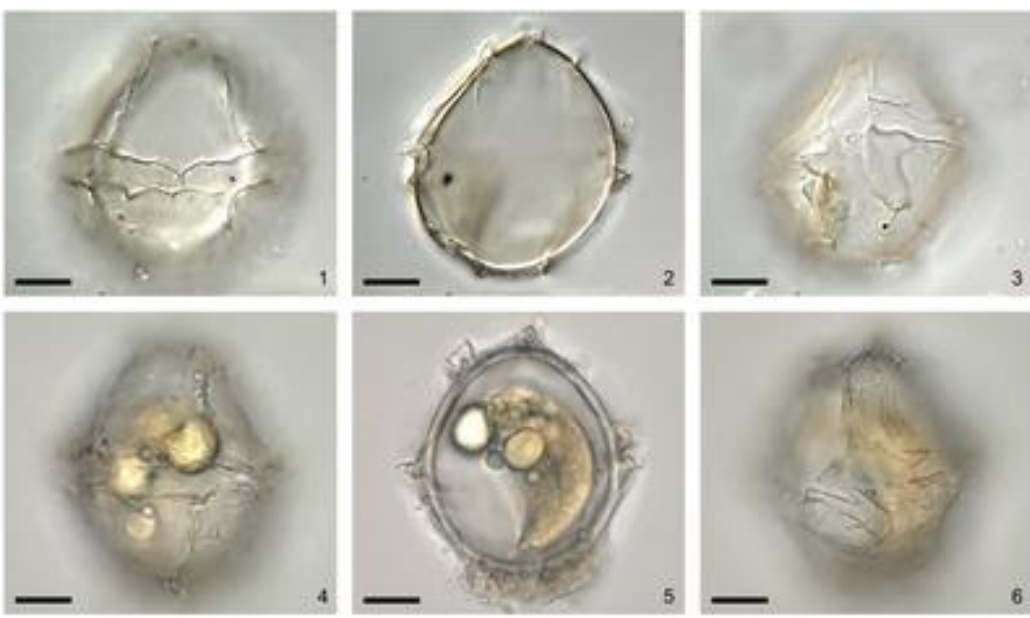

Download : Download high-res image (2MB)

Download : Download full-size image

Plate 6.1-6. Cyst of Gonyaulax baltica. 1-3. High to low focus, dorsal view, of specimen from Limfjord (Denmark). 4-6. High to low focus of specimen with cell content from Langden Station, Tvärminne (Gulf of Finland) surface sediments. All images by KNM. All scale bars $=10 \mu \mathrm{m}$. 

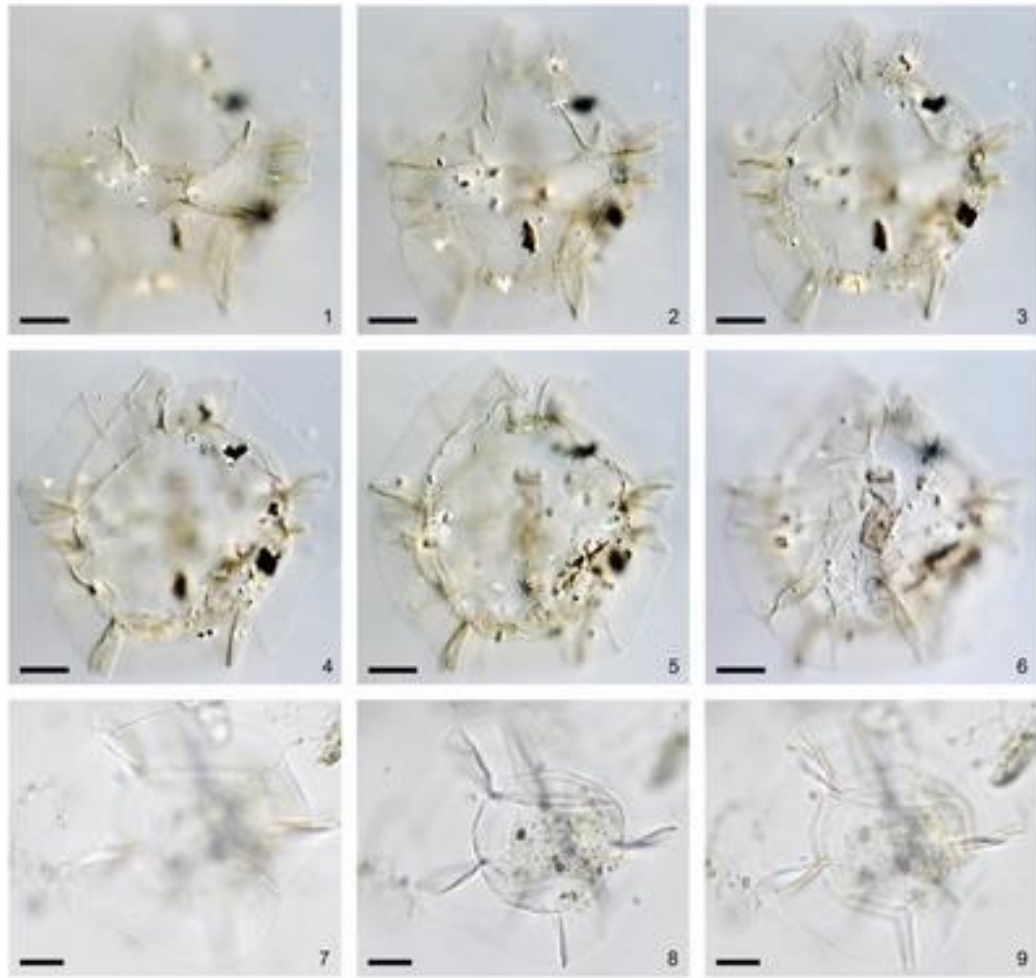

Download : Download high-res image (3MB)

Download : Download full-size image

Plate 7.1-6. Impagidinium japonicum. 1-6. New micrographs of the holotype (Matsuoka, 1983). High to low focus, dorsal view. 7-9. Impagidinium velorum, specimen from the latest Pliocene of the central North Atlantic Ocean (IODP Hole U1313C; from Hennissen, 2013). 7. Focus on the microgranulate wall of the central body. 8. Optical section. 9. Focus on the sutural crests. 1-6 by MJH, 7-9 by Jan A.I. Hennissen. All scale bars $=10 \mu \mathrm{m}$. 

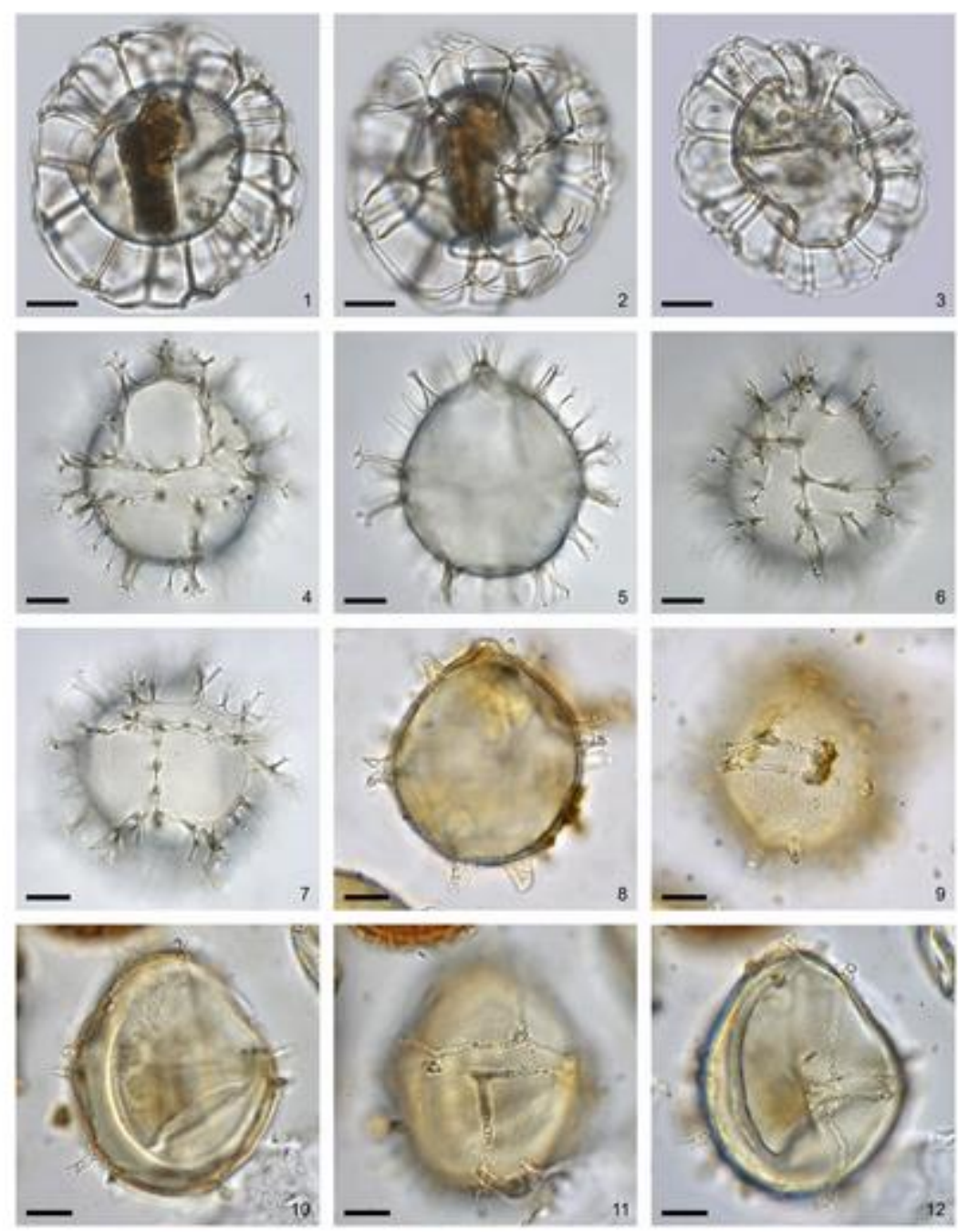

Download : Download high-res image (4MB)

Download : Download full-size image

Plate 8. 1-3. Nematosphaeropsis rigida. 1-2. Optical section and low focus on specimen from the Gulf of Mexico (Limoges et al., 2013). 3. Optical section of a different specimen from the same locality. 4-7. Spiniferites hainanensis from Southern China surface sediments. 4-6. Increasing focal depth, dorsal view. 7. Oblique dorso-lateral view of the hypocyst. 8-12. Spiniferites multisphaerus. 8-9. Optical section and low focus on specimen from the Pacific Ocean. 10-12. Different focal depths of a different specimen from the Pacific Ocean. Image 1-3 by AL, $4-7$ by $\mathrm{KNM}, 8-12$ by VP. All scale bars $=10 \mu \mathrm{m}$. 

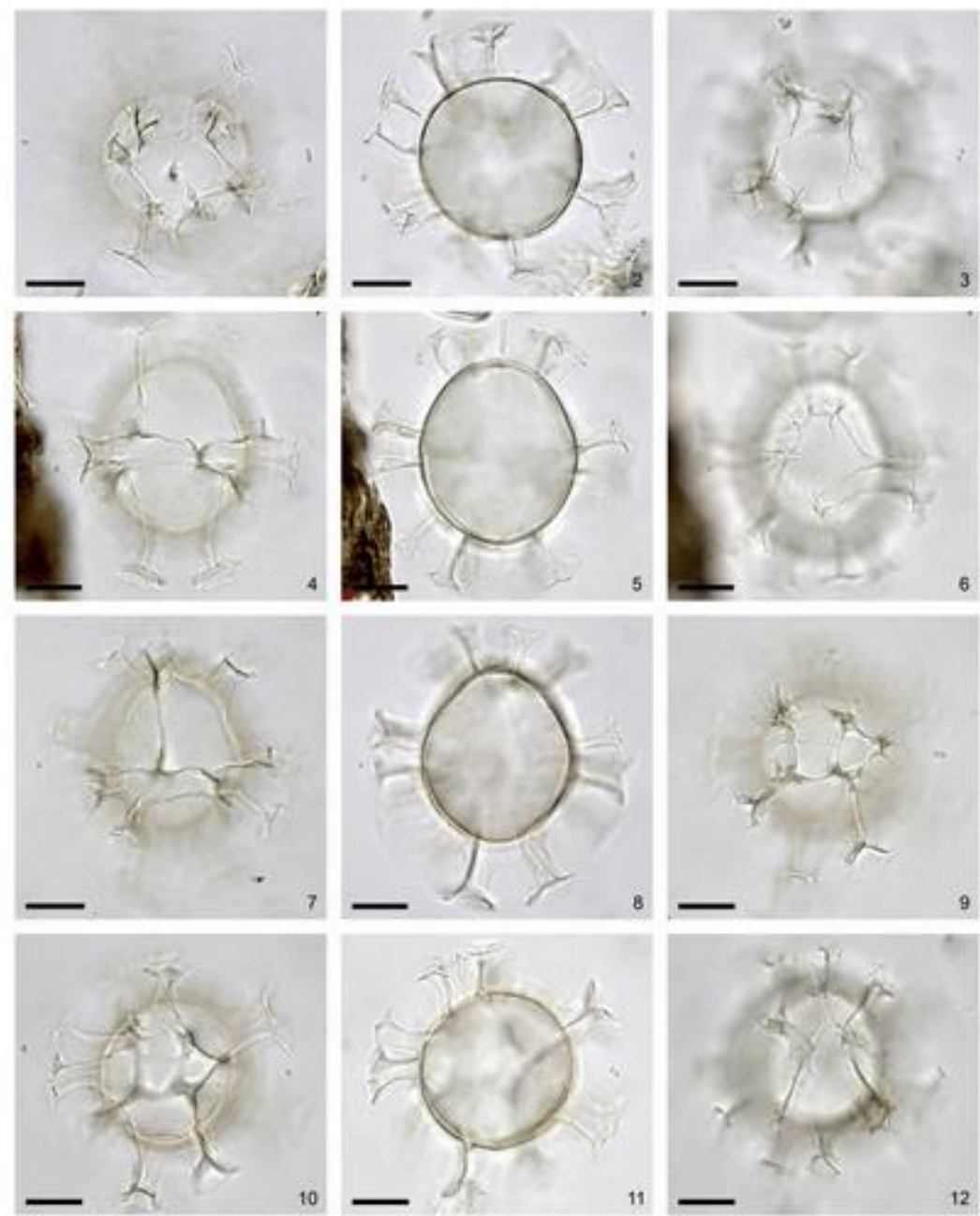

Download : Download high-res image (4MB)

Download : Download full-size image

Plate 9. 1-12. Spiniferites ristingensis, specimens from (sub)surface sediments off Portugal (core PO287-39B, Ribeiro et al., 2016). 1-3. High to low focus, apical view. 4-6. High to low focus, dorsal view. 7-8. High and mid-focus, dorso-lateral view. 9-12. High to low focus, oblique antapical view. All images by KNM. All scale bars $=10 \mu \mathrm{m}$. 

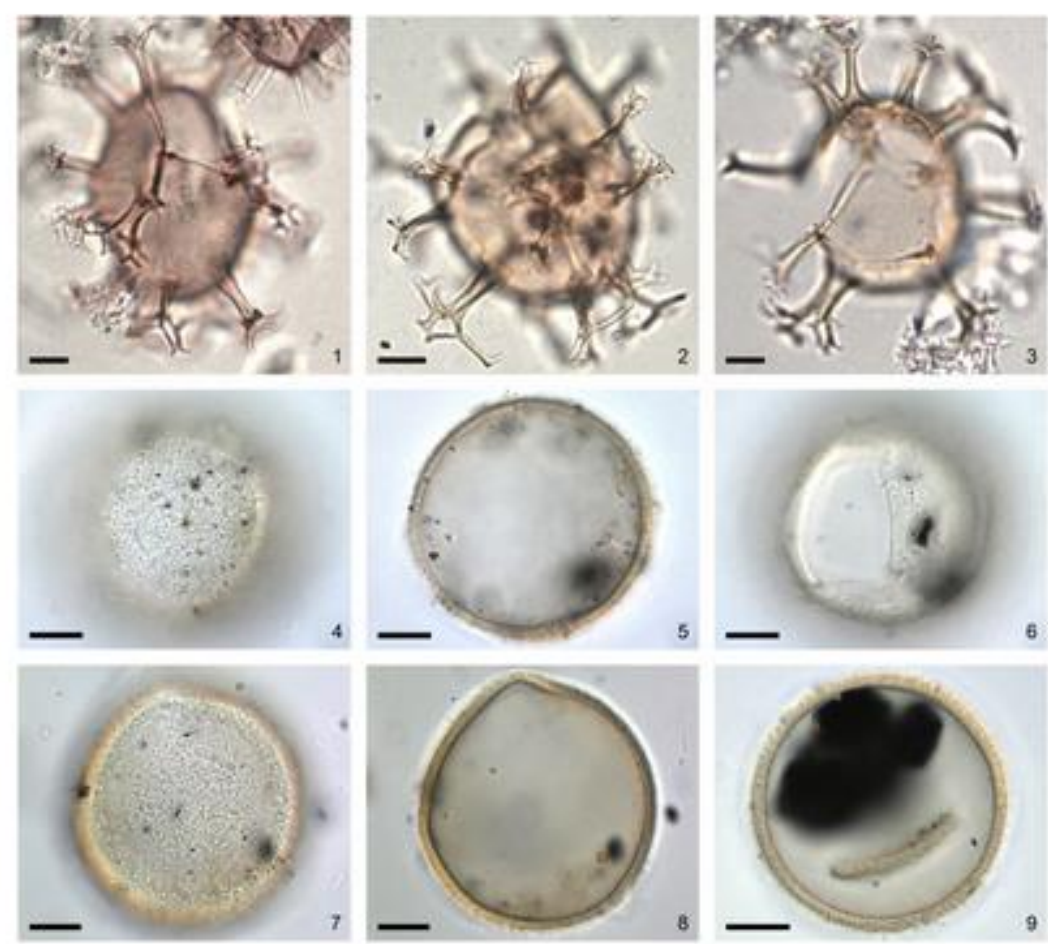

Download : Download high-res image (3MB)

Download : Download full-size image

Plate 10.1-3. Spiniferits septentrionalis, three specimens from MIS 6 in the Bay of Biscay (core MD03-2692, Penaud et al., 2008). 4-9.

Tectatodinium pellitum from the eastern Mediterranean Sea. 4-6. High to low focus, ventro-lateral view. 7-8. High focus and optical section of a different specimen. 9. Optical section of another specimen. Image 1-3 by Aurélie Penaud, 4-9 by KNM. All scale bars $=10 \mu \mathrm{m}$. 

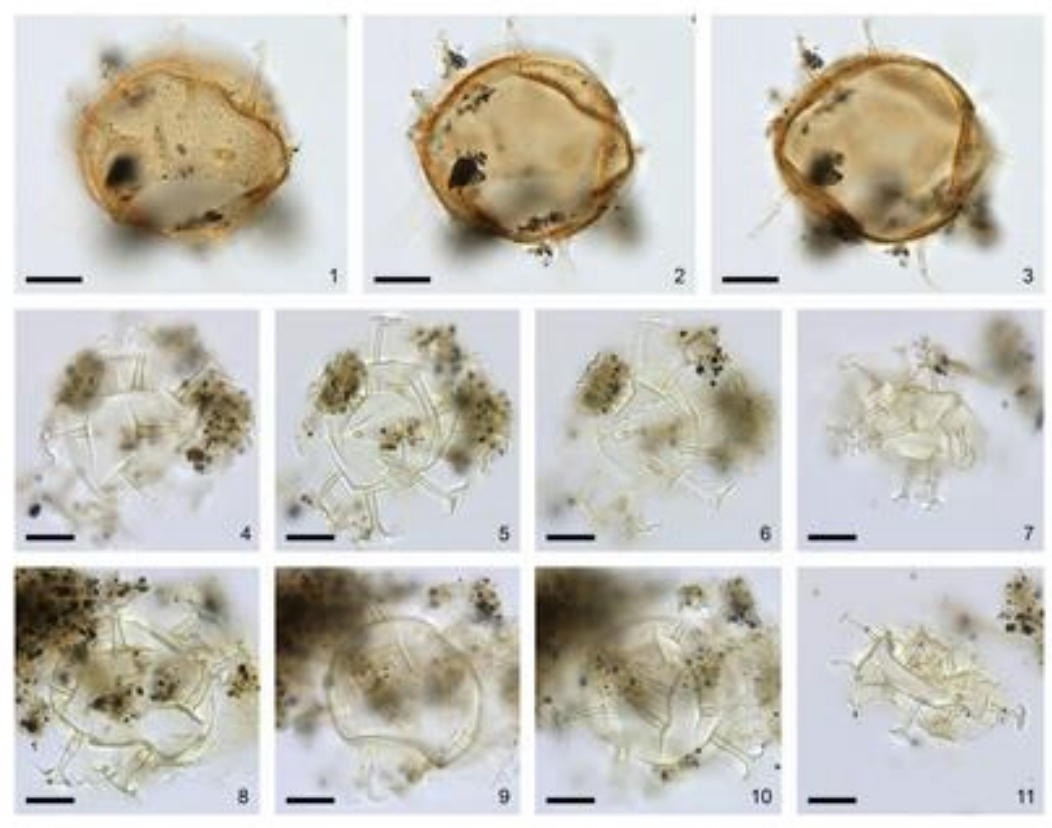

Download : Download high-res image (3MB)

Download : Download full-size image

Plate 11.1-3. Melitasphaeridium angustum, new micrographs of the holotype (Matsuoka, 1983). Apical view in (1) high focus and (2-3) optical section at two slightly different focal depths. 4-11.

Melitasphaeridium choanophorum from the Gulf of Mexico. 4-6. High to low focus. 7, 11. Different focal depths of different specimen. 8-10. High to low focus of another specimen. Image 1-3 by KNM, 4-11 by AL. All scale bars $=10 \mu \mathrm{m}$. 

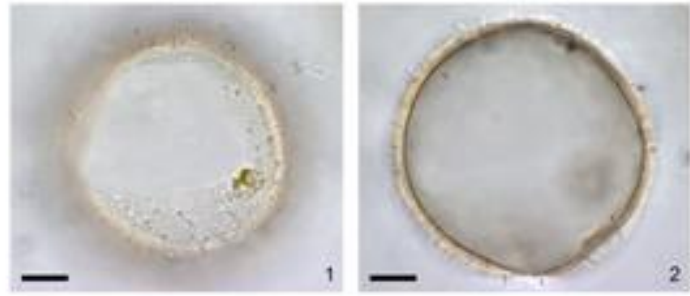

2
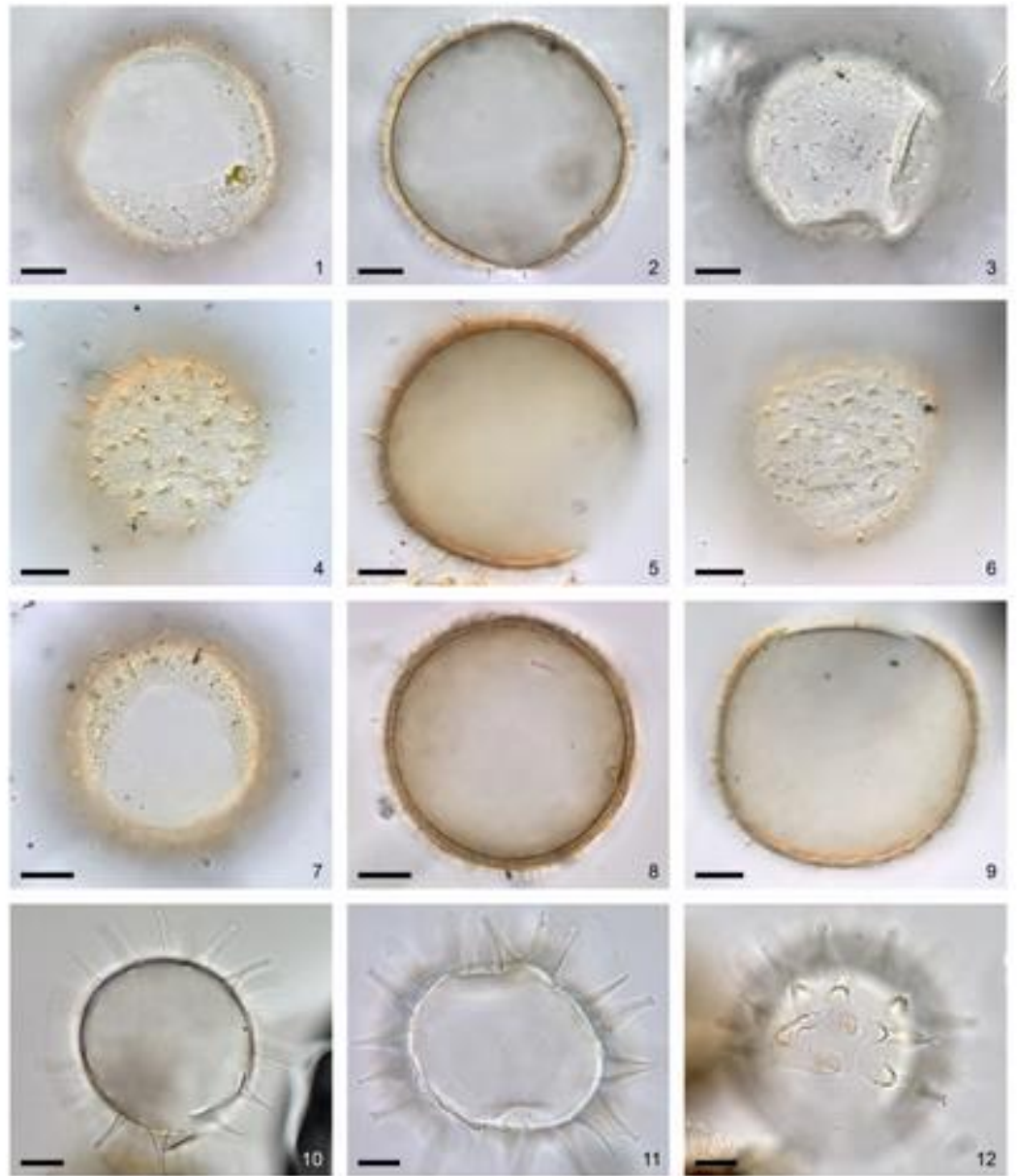

Download : Download high-res image ( $4 M B$ )

Download : Download full-size image

Plate 12.1-9. Cyst of Pentaplacodinium saltonense from Salton Sea (California, USA) surface sediments. 1-3. High to low focus, dorsal view. 4-5. High focus and optical section of a different specimen. 6, 9. High focus and optical section of a different specimen. 7-8. High focus and optical section of another specimen. 10-12. Dapsilidinium pastielsii, three different specimens from the Phillippines. All images by KNM. All scale bars $=10 \mu \mathrm{m}$. 

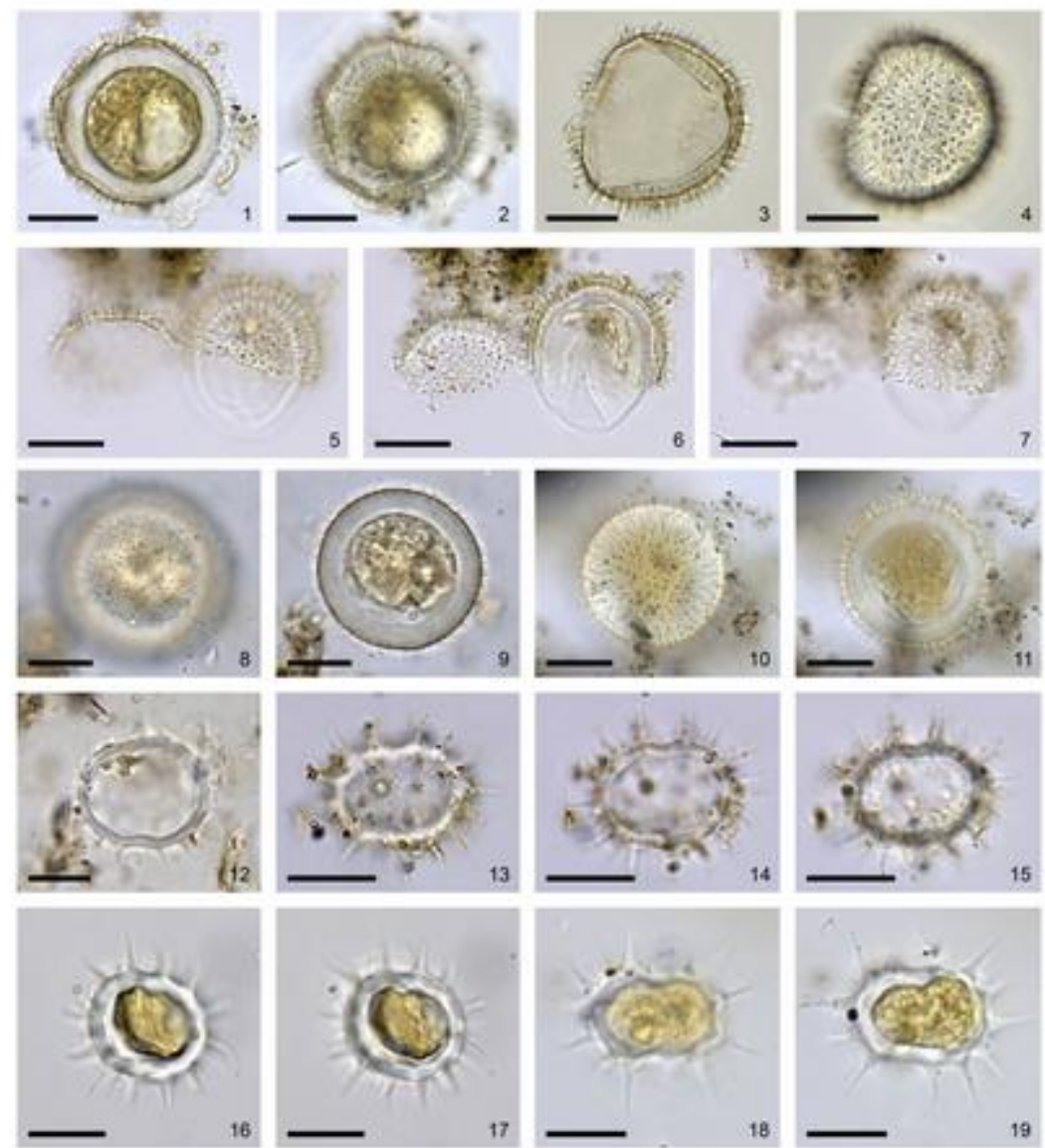

Download : Download high-res image ( $4 \mathrm{MB}$ )

Download : Download full-size image

Plate 13. 1-7. Cyst of Biecheleria baltica from the Baltic Sea (core KSK12-01D). 1-2. Optical section and low focus of specimen with cell content. 3-4. High focus showing the (?) archeopyle, and low focus, of a different specimen. 5-7. High to low focal view of another specimen suggesting an epicystal archeopyle. 8-11. Cyst of cf. Biecheleria baltica. 8-9. High focus and optical section of specimen with cell content from the Arctic. 10-11. High focus and optical section of specimen with cell content from NE Greenland. 12-19. Cyst of Polarella glacialis. 12. Optical section of specimen from the Arctic. 13-15. High to low focus of specimen from northern Baffin Bay. 16-17. Different focal depths of a specimen with cell content from northern Baffin Bay. 18-19. Different focal depths of specimen with cell content from the Wandel Sea. Image 1-7, 13-17 by NVN, 8-9, 12 by VP, 10-11, 18-19 by AL. All scale bars $=10 \mu \mathrm{m}$. 